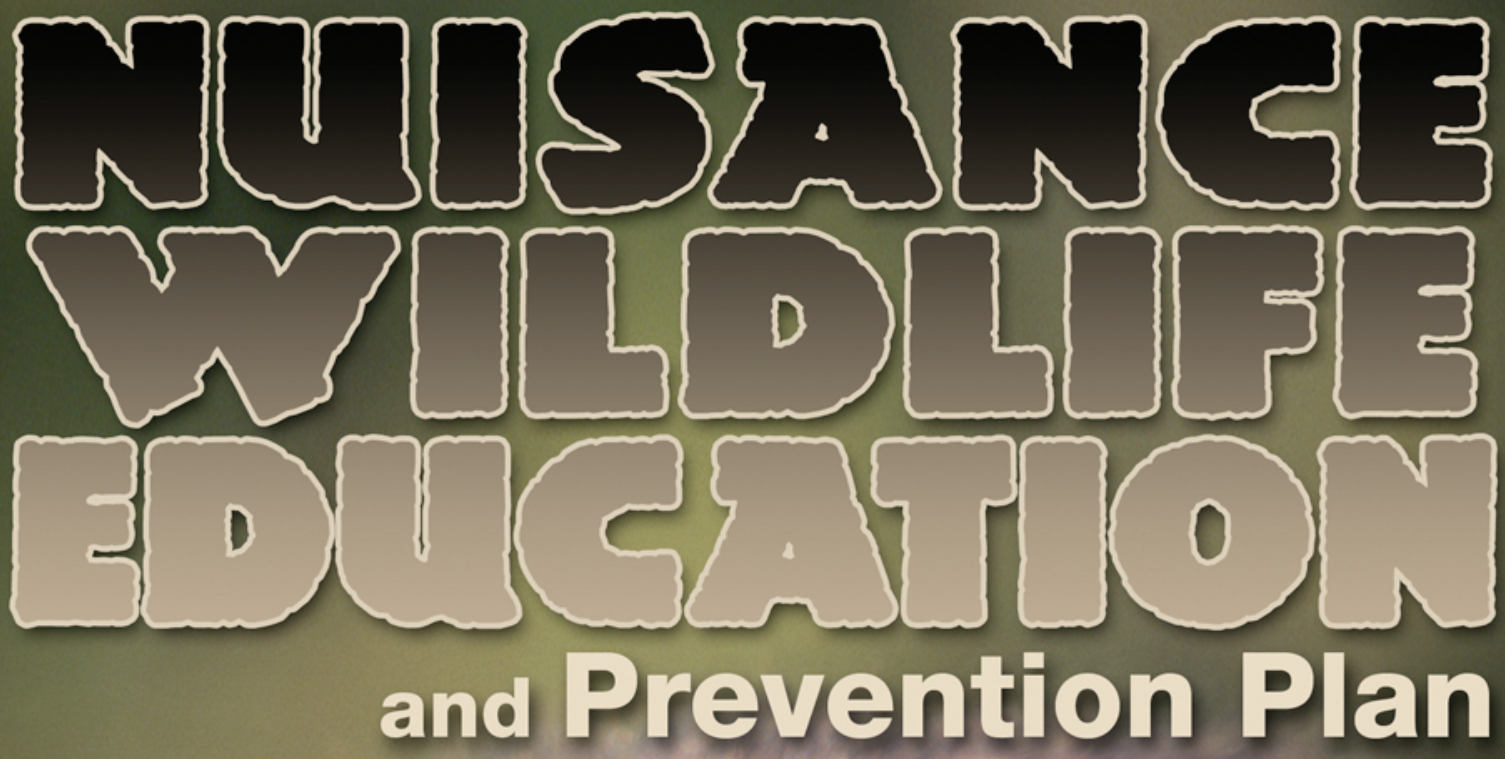
for the OAKS RIDGE NAJIONAL LABORATORY

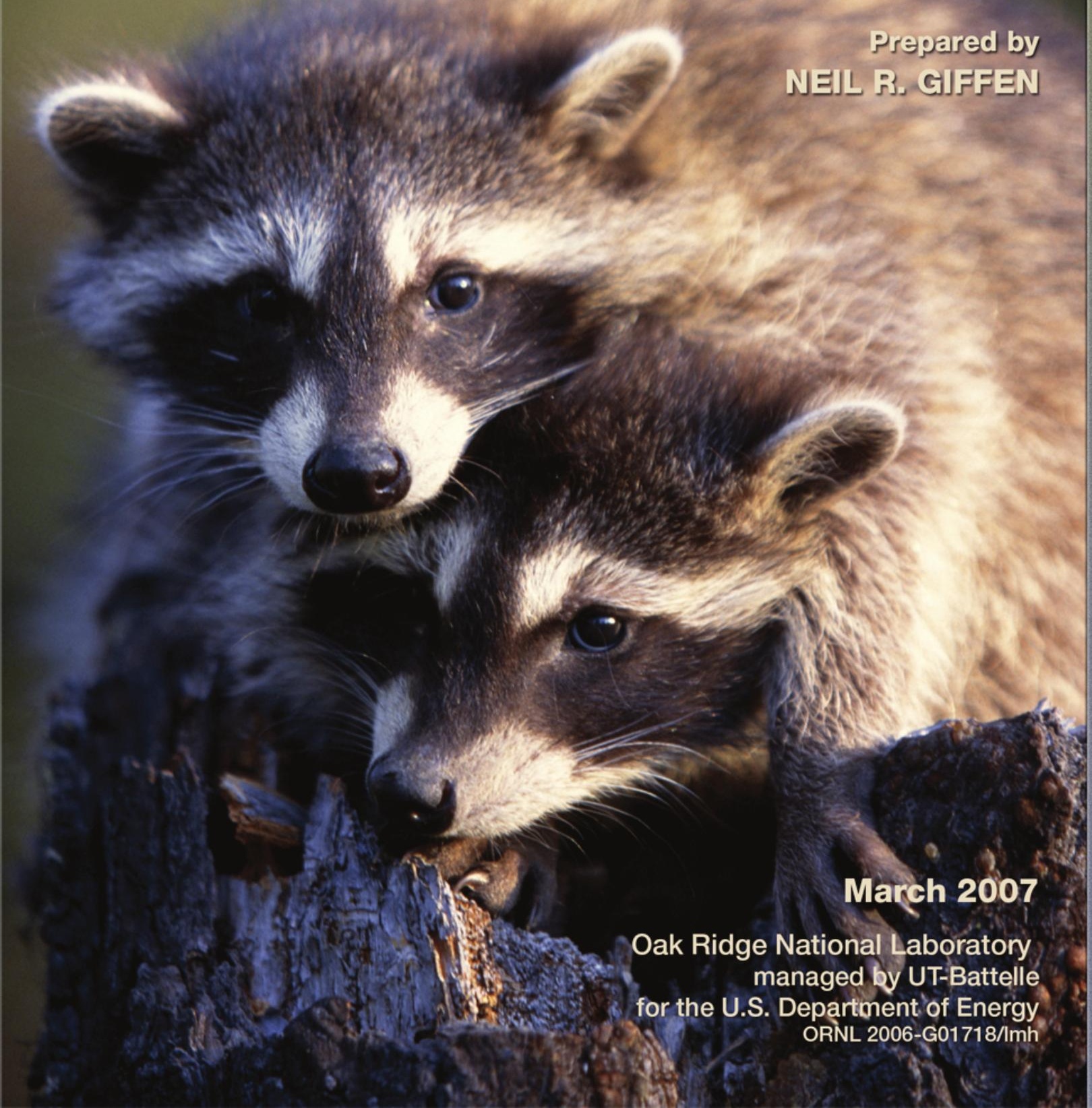




DOCUMENT AVAILABILITY
Reports produced after January 1, 1996, are generally available free via the U.S.
Department of Energy (DOE) Information Bridge.
Web site http://www.osti.gov/bridge
Reports produced before January 1, 1996, may be purchased by members of the public from
the following source.
National Technical Information Service
5285 Port Royal Road
Springfield, VA 22161
Telephone 703-605-6000 (1-800-553-6847)
TDD 703-487-4639
Fax 703-605-6900
E-mail info@ntis.gov
Web site http://www.ntis.gov/support/ordernowabout.htm
Reports are available to DOE employees, DOE contractors, Energy Technology Data
(INIS)
Exchange InE) representatives, and International Nuclear Information System
representatives from the following source.
Office of Scientific and Technical Information
P.O. Box 62
Oak Ridge, TN 37831
Telephone 865-576-8401
Fax 865-576-5728
Web site http://www.osti.gov/contact.html

This report was prepared as an account of work sponsored by an agency of the United States Government. Neither the United States Government nor any agency thereof, nor any of their employees, makes any warranty, express or implied, or assumes any legal liability or responsibility for the accuracy, completeness, or usefulness of any information, apparatus, product, or process disclosed, or represents that its use would not infringe privately owned rights. Reference herein to any specific commercial product, process, or service by trade name, trademark, manufacturer, or otherwise, does not necessarily constitute or imply its endorsement, recommendation, or favoring by the United States Government or any agency thereof. The views and opinions of authors expressed herein do not necessarily state or reflect those of the United States Government or any agency thereof. 


\title{
NUISANCE WILDLIFE EDUCATION AND PREVENTION PLAN FOR THE OAK RIDGE NATIONAL LABORATORY
}

Neil R. Giffen

Environmental Sciences Division

March 2007

\author{
Prepared by \\ OAK RIDGE NATIONAL LABORATORY \\ P.O. Box 2008 \\ Oak Ridge, Tennessee 37831-6283 \\ managed by \\ UT-BATTELLE, LLC \\ for the \\ U.S. DEPARTMENT OF ENERGY \\ under contract DE-AC05-00OR2272
}





\section{CONTENTS}

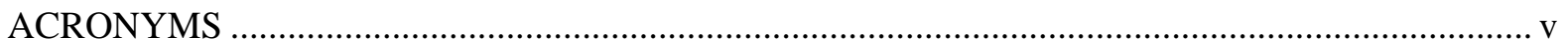

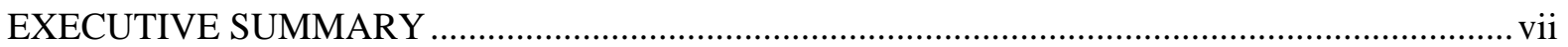

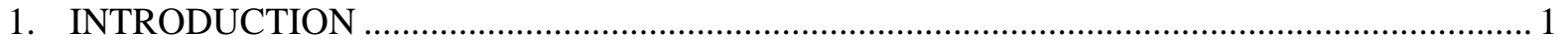

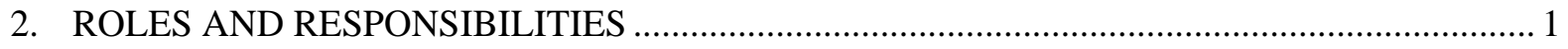

2.1 OAK RIDGE RESERVATION WILDLIFE MANAGEMENT COORDINATOR.............. 1

2.2 TENNESSEE WILDLIFE RESOURCES AGENCY WILDLIFE MANAGER ................... 1

2.3 UNITED STATES DEPARTMENT OF AGRICULTURE, WILDLIFE SERVICES.......... 1

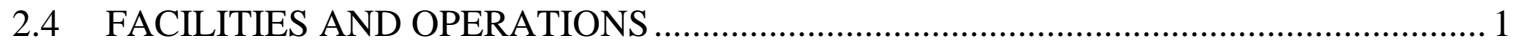

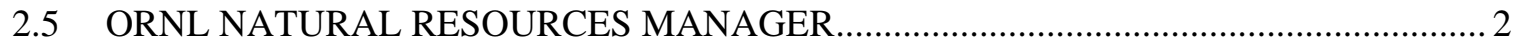

3. GENERAL PROTOCOL FOR REDUCING NUISANCE WILDLIFE PROBLEMS .................. 2

4. SPECIES-SPECIFIC NUISANCE WILDLIFE MANAGEMENT ….......................................... 3

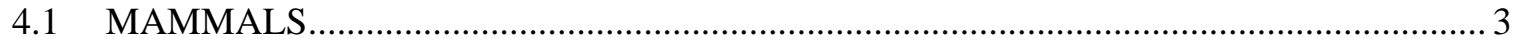

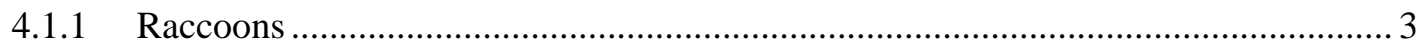

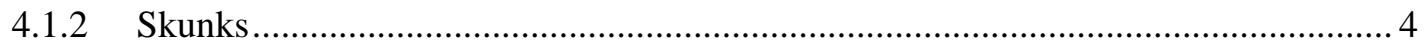

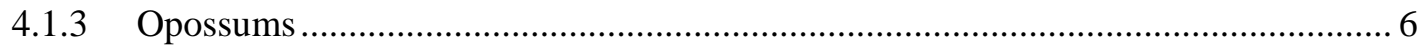

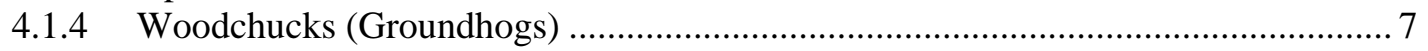

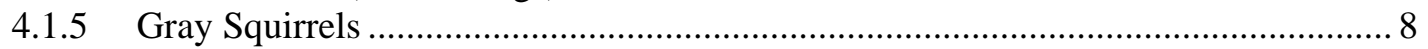

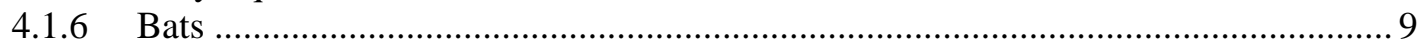

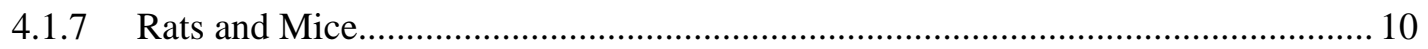

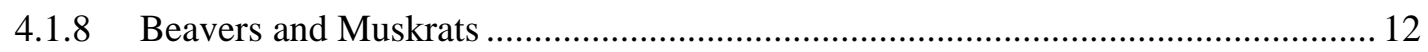

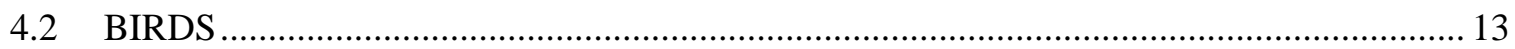

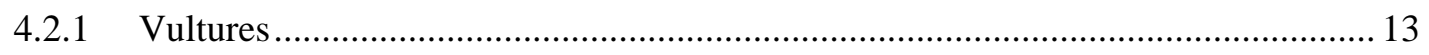

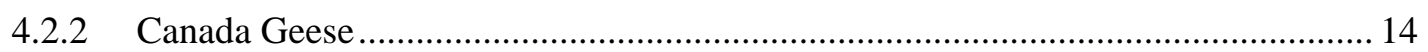

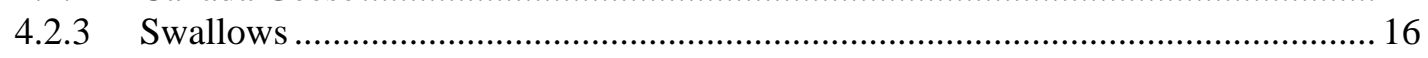

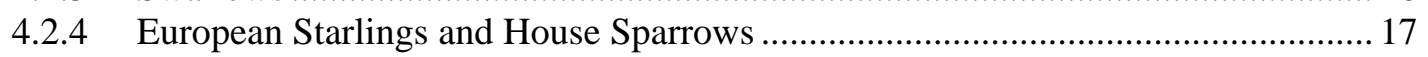

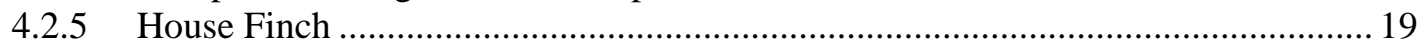

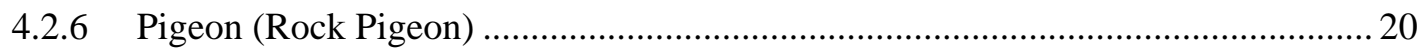

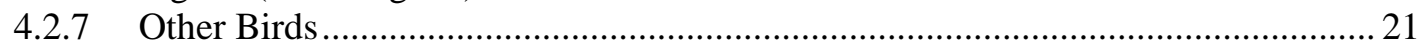

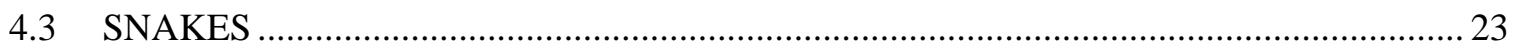

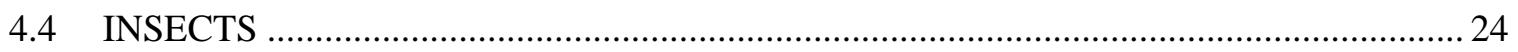

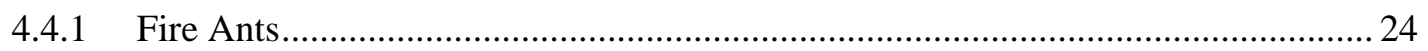

4.4.2 Paper Wasps, Bald-faced Hornets, and Yellowjackets ........................................ 25

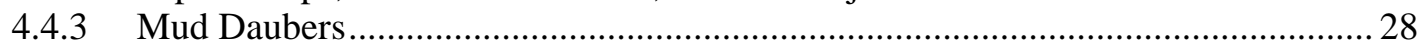

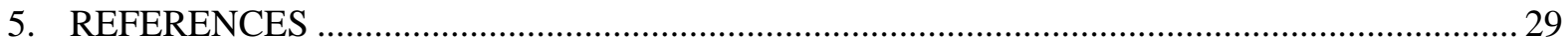





\section{ACRONYMS}

$\begin{array}{ll}\text { APHIS } & \text { Animal and Plant Health Inspection Service } \\ \text { F\&O } & \text { facilities and operations } \\ \text { HPS } & \text { hantavirus pulmonary syndrome } \\ \text { ORNL } & \text { Oak Ridge National Laboratory } \\ \text { ORR } & \text { Oak Ridge Reservation } \\ \text { TWRA } & \text { Tennessee Wildlife Resources Agency } \\ \text { USDA } & \text { United States Department of Agriculture } \\ \text { USFWS } & \text { U. S. Fish and Wildlife Service } \\ \text { WS } & \text { Wildlife Services }\end{array}$





\section{EXECUTIVE SUMMARY}

This document outlines a plan for management of nuisance wildlife at the Oak Ridge National Laboratory (ORNL). Nuisance wildlife management includes wildlife population control through hunting, trapping, removal, and habitat manipulation; wildlife damage control; and law enforcement. This plan covers the following subjects: (1) roles and responsibilities of individuals, groups, and agencies; (2) the general protocol for reducing nuisance wildlife problems; and (3) species-specific methodologies for resolving nuisance wildlife management issues for mammals, birds, snakes, and insects. Achievement of the objectives of this plan will be a joint effort between the Tennessee Wildlife Resources Agency (TWRA); U. S. Department of Agriculture (USDA), Animal and Plant Health Inspection Service (APHIS)-Wildlife Services (WS); and ORNL through agreements between TWRA and the U.S. Department of Energy (DOE); DOE and UT-Battelle, LLC; and UT-Battelle, LLC; and USDA, APHIS-WS. 



\section{INTRODUCTION}

The Oak Ridge National Laboratory (ORNL) property supports more than 275 wildlife species (i.e., birds, mammals, reptiles, and amphibians). The activities of the majority of these species do not result in any conflicts with people. However, certain species cause nuisance problems. These species tend to be those that are more adaptable to the urban/suburban environment. Human/wildlife interactions can cause health and safety concerns that must be remedied using wildlife management tools, changes in human behavior, and institutional controls. The chosen remedy is dependent upon the species involved and the circumstances. Particular wildlife species, such as Canada geese, pigeons, raccoons, skunks, opossums, woodchucks (groundhogs), bats, fire ants, and a variety of snakes, present nuisance issues on a regular basis. Other species cause only occasional concerns. These latter species tend to be those that only periodically venture into areas with human activity.

This plan outlines the types of persistent nuisance problems that occur at ORNL and presents information on dealing with these concerns and resolving issues on a long-term basis.

The following information describes roles and responsibilities related to the ORNL area.

\section{ROLES AND RESPONSIBILITIES}

\subsection{OAK RIDGE RESERVATION WILDLIFE MANAGEMENT COORDINATOR}

The Oak Ridge Reservation (ORR) Wildlife Management Coordinator provides advice and facilitates the resolution of nuisance wildlife management concerns at the Department of Energy facilities and for the ORR land area. Neil Giffen of the ORNL Environmental Sciences Division is the ORR Wildlife Management Coordinator.

\subsection{TENNESSEE WILDLIFE RESOURCES AGENCY WILDLIFE MANAGER}

The Tennessee Wildlife Resources Agency (TWRA) wildlife manager responds to nuisance wildlife problems on an as-needed basis by providing advice, supplying traps, and picking up trapped animals for removal. TWRA's general duties do not include intensive nuisance wildlife trapping and responses. Jim Evans of TWRA is the wildlife manager to contact for ORR issues.

\subsection{UNITED STATES DEPARTMENT OF AGRICULTURE, WILDLIFE SERVICES}

The United States Department of Agriculture (USDA), Animal and Plant Health Inspection Service (APHIS)-Wildlife Services (WS) responds to large-scale nuisance wildlife problems, along with those issues that require specialized methods. Keith Blanton, a wildlife biologist with USDA, APHIS-WS is the person to contact for ORR issues.

\subsection{FACILITIES AND OPERATIONS}

The facilities and operations (F\&O) team at ORNL is responsible for implementing maintenance practices aimed at minimizing entry of wildlife into buildings and other facilities. Each facility will be responsible for monitoring nuisance wildlife issues and coordinating with the ORR Wildlife Management Coordinator, TWRA wildlife manager, and/or USDA wildlife biologist to remedy the problem. 


\subsection{ORNL NATURAL RESOURCES MANAGER}

The ORNL Natural Resources Manager is responsible for integration of wildlife management needs with overall management of ORNL and ORR natural resources. Pat Parr of the F\&O Directorate is the ORNL Natural Resources Manager.

\section{GENERAL PROTOCOL FOR REDUCING NUISANCE WILDLIFE PROBLEMS}

The following guidelines should be adhered to in efforts to reduce nuisance wildlife problems at ORNL:

- Do not transport wild and domestic animals from off-site onto the Reservation.

- Do not release nuisance wildlife trapped at ORNL to other areas. These animals should be euthanized. (Transport of animals to other areas of the ORNL property or off-site will only be done in certain special cases under TWRA direction.) Any trapped feral cats should be taken to the animal shelter.

- Do not feed resident wildlife and feral cats.

- Secure all dumpsters and other garbage receptacles to avoid providing a steady food supply to potential nuisance animals.

- Keep building maintenance informed of problems to prevent entry of animals through holes, broken windows, etc.

- Use building maintenance and construction techniques that will minimize the potential for entry by wildlife.

The justifications for adhering to the above guidelines are the following:

- Release of animals from other areas to ORNL property will only increase the current problem.

- The feeding of resident wildlife and feral cats provides a steady food supply, resulting in sustained and increased nuisance wildlife problems. It also increases the chances of wildlifehuman interactions that can cause health and safety concerns for the employees.

- The release of ORR nuisance wildlife to other areas could result in the increase of nuisance problems in that area (i.e., by transferring the problem to someone else), result in the spread of disease, and introduce "foreign" animals into a situation in which they might be unable to compete with resident animals for existing resources.

- USDA, APHIS-WS requires euthanasia rather than relocation of all raccoons and skunks trapped in east Tennessee counties because of concerns regarding the potential spread of rabies. 


\section{SPECIES-SPECIFIC NUISANCE WILDLIFE MANAGEMENT}

\subsection{MAMMALS}

The main mammals causing nuisance problems on the ORR are raccoons, skunks, opossums, woodchucks (groundhogs), gray squirrels, bats, rats, mice, and beavers.

\subsubsection{Raccoons}

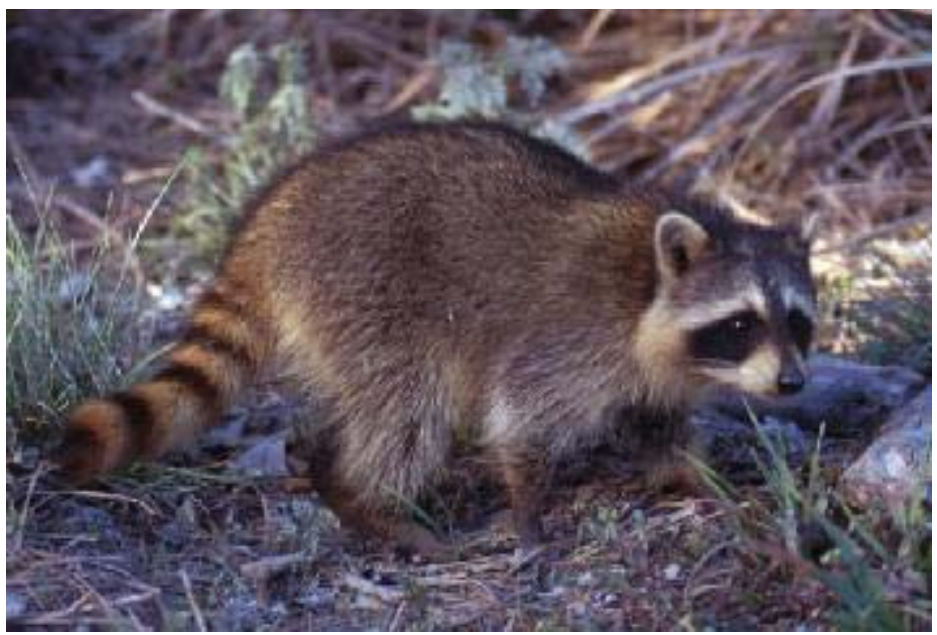

\section{Nuisance Concerns}

Raccoons can be a nuisance where they gain entrance to buildings, garbage cans, and dumpsters. Raccoons are opportunistic and will enter buildings where the possibility exists. Broken crawl-space vent screens and other openings at the base of buildings can provide such entryways. Raccoons will enter in search of food and den sites. They can easily climb to upper floors between walls and actually enter office space through loose ceiling tiles.

Raccoons are common visitors to dumpsters, where they take advantage of this readily available food source. Raccoons can typically open unlatched dumpster covers and doors with ease.

\section{Remedies}

Prevention is the main way to eliminate unwanted contact with raccoons. Raccoons will commonly use attics and other unoccupied spaces in buildings as den sites. All building roofs, soffits, walls, and windows should be kept in good repair to prevent entry. Branches overhanging buildings should also be cut back to limit access to the roof and soffit areas (USDA 1994). All crawl-space vents, another common point of entry, should be in good repair. There are two things to remember: (1) raccoons are nocturnal and should be out foraging at night, and (2) they will generally have young in their den sites during April and May (Chapman and Feldhamer 1982). Caution should be taken when closing existing openings so as not to trap animals inside. If there are several points of entry, it is always a good practice to leave one open for a day or two to ensure that all the animals are out before completely sealing the area. Fresh tracks can be detected in flour left at the entrance. After you are sure that the den is empty, you should immediately seal the remaining entrance. Another option would be to construct a one-way door that would allow access out but not back in. The ORR Wildlife Management Coordinator or TWRA wildlife manager can be contacted for advice on identifying and closing entry points. 
The use of commercially available animal-proof dumpsters is highly recommended to fully remedy chronic problems with foraging raccoons. If such dumpsters cannot be used at the facility, then modifications to existing dumpsters should include the installation of tight-fitting, latched covers and latches placed on other access doors. Any outside garbage cans should be fitted with tight-fitting lids fastened with bungee cords or latches, and/or they should be housed in a structure that can be fully closed (USDA 1994).

\section{Removal Methods}

Raccoons can be livetrapped relatively easily using fish-flavored cat food, sardines, other fish, or chicken for bait (USDA 1994).

Live traps can be obtained from the TWRA wildlife manager. The wildlife manager can also provide advice on baiting and the size of trap to use. Once the animal is trapped, TWRA will complete its removal. The employee should not handle the animal in any way because of the possibility of disease. TWRA wildlife managers are trained to handle these animals and are properly vaccinated against disease.

\section{Disease Concerns}

Raccoons can carry diseases such as rabies or distemper. Typical signs of rabies include drooling, convulsions, circling, disorientation, partial paralysis, unprovoked aggression, and uncharacteristic tameness. Distemper, although not contagious to humans, will cause similar symptoms in the animal. If a raccoon bites someone, the animal should be captured without damaging the head and kept for analysis. The ORNL Medical Division should be contacted immediately for treatment of the individual bitten. The ORR Wildlife Management Coordinator or TWRA wildlife manager should be contacted to aid in capturing the raccoon for testing. USDA, APHIS-WS will analyze the animal for rabies.

\subsubsection{Skunks}

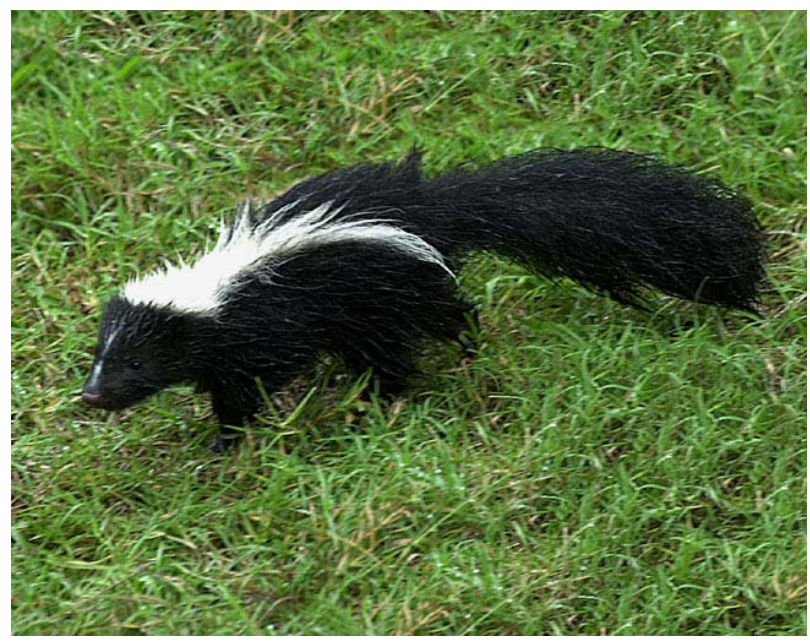

\section{Nuisance Concerns}

Skunks can be a nuisance where they gain entrance into and under buildings. Skunks are opportunistic and will enter buildings where the possibility exists. Broken crawl-space vent screens 
and other openings at the base of buildings can provide such entryways. Skunks will enter in search of food and den sites.

\section{Remedies}

Prevention is the main way to eliminate unwanted contact with skunks. Skunks become a nuisance when their burrowing and feeding habits conflict with humans. They will burrow under porches or buildings by entering foundation openings (USDA 1994). All crawl-space vents, a common point of entry, should be in good repair. There are two things to remember: (1) skunks are nocturnal and should be out foraging at night, and (2) they will generally have young in their den sites (e.g., under floors of buildings) during April and May (Chapman and Feldhamer 1982). Caution should be taken when closing existing openings so as not to trap animals inside. If there are several points of entry, it is always a good practice to leave one open for a day or two to ensure that all the skunks are out before completely sealing the area. Fresh tracks can be detected in flour left at the entrance. After you are sure that the den is empty, you should immediately seal the remaining entrance (Harper, Byford, and Dixon 2003). Another approach would be to construct a one-way door that will allow access out but not back in. The ORR Wildlife Management Coordinator or TWRA wildlife manager can be contacted for advice on identifying and closing entry points.

Any outside garbage cans should be fitted with tight-fitting lids fastened with bungee cords or latches, and/or they should be housed in a structure that can be fully closed (USDA 1994).

\section{Removal Methods}

Skunks can be livetrapped relatively easily using sardines, fish-flavored cat food, chicken entrails, or peanut butter for bait (USDA 1994). It is generally recommended that wire live traps be covered with canvas or other covering to give the trapped animal a secure feeling, which will minimize the chance that the animal will discharge its scent (Harper, Byford, and Dixon 2003). Skunk traps are also commercially available that provide the concealment required, eliminating the need to drape the trap.

Live traps can be obtained from the TWRA wildlife manager. The wildlife manager can also provide advice on baiting and the size of trap to use. Once the animal is trapped, TWRA will complete its removal. The employee should not handle the animal in any way because of the possibility of disease and/or spraying. TWRA wildlife managers are trained to handle these animals and are properly vaccinated against disease.

\section{Disease Concerns}

Skunks can carry diseases such as rabies or distemper. Typical signs of rabies include drooling, convulsions, circling, disorientation, partial paralysis, unprovoked aggression, and uncharacteristic tameness. Distemper, although not contagious to humans, will cause similar symptoms in the animal. If a skunk bites someone, the animal should be captured without damaging the head and kept for analysis. ORNL Medical should be contacted immediately for treatment of the individual bitten. The ORR Wildlife Management Coordinator or TWRA wildlife manager should be contacted to aid in capturing the skunk for testing. USDA, APHIS-WS will analyze the animal for rabies. 


\subsubsection{Opossums}

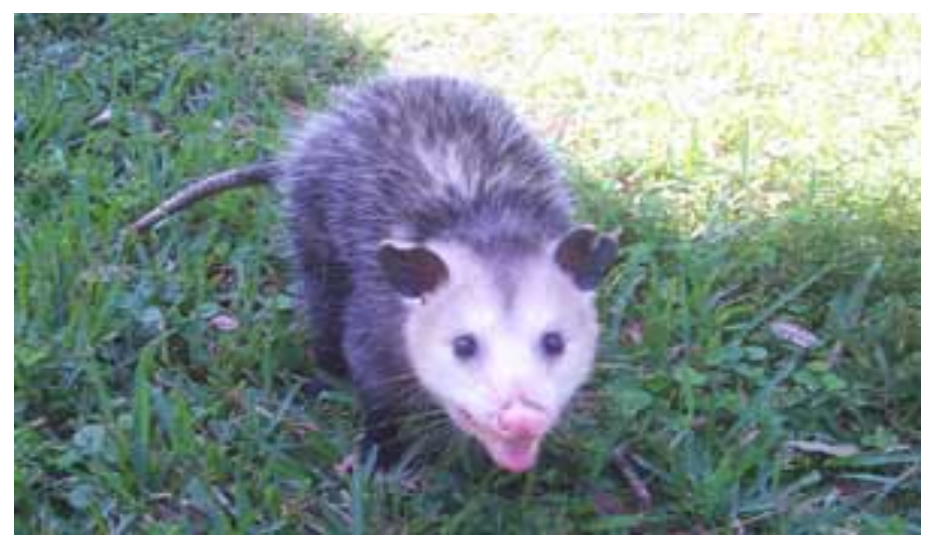

\section{Nuisance Concerns}

The opossum is the only marsupial found in North America. It is a lumbering animal, lacking the agility of a raccoon. Opossums are common visitors to garbage cans and dumpsters. As with raccoons and skunks, opossums can and will enter buildings in search of den sites where opportunities exist. Broken crawl-space vent screens and other openings at the base of buildings provide such entryways. Opossums are capable climbers and can end up in attics, where they will make a messy nest.

\section{Remedies}

Prevention is again the main way to eliminate unwanted contact with opossums. All crawl-space vents, a common point of entry, should be in good repair. Opossums are nocturnal and should be out foraging at night. They give birth to very underdeveloped young that remain in the mother's pouch for 70 to 85 days after birth. The mother will then leave them in the den (e.g., in an attic or other area of a building) while out foraging. The young might occasionally leave the den during this time with the mother, either riding on her back or running beside her. The young become fully independent around day 108 (Chapman and Feldhamer 1982). Caution should be taken when closing existing openings so as not to trap animals inside; however, this might be difficult to judge because of the great variability in the opossum's breeding scheme. If there are several points of entry, it is always good practice to leave one open for a day or two to ensure that all the animals are out before completely sealing the area. Fresh tracks can be detected in flour left at the entrance. After you are sure that the den is empty, you should immediately seal the remaining entrance. Another approach would be to construct a one-way door that will allow access out and not back in.

The use of commercially available animal-proof dumpsters is highly recommended to fully remedy chronic problems with foraging opossums. If such dumpsters cannot be used at the facility, then modifications to existing dumpsters should include the installation of tight-fitting, latched covers and latches placed on other access doors. Any outside garbage cans should be fitted with tight-fitting lids fastened with bungee cords or latches, or they should be housed in a structure that can be fully closed (USDA 1994).

\section{Removal Methods}

Opossums can be livetrapped relatively easily using cheese, slightly spoiled meat, fish, or fruit as bait.

Live traps can be obtained from the TWRA wildlife manager. The wildlife manager can also provide advice on baiting and the size of trap to use. Once the animal is trapped, TWRA will 
complete its removal. The employee should not handle the animal in any way because of the possibility of disease. TWRA wildlife managers are trained to handle these animals and are properly vaccinated against disease.

\section{Disease Concerns}

Opossums can occasionally carry rabies, but those cases are rare.

\subsubsection{Woodchucks (Groundhogs)}

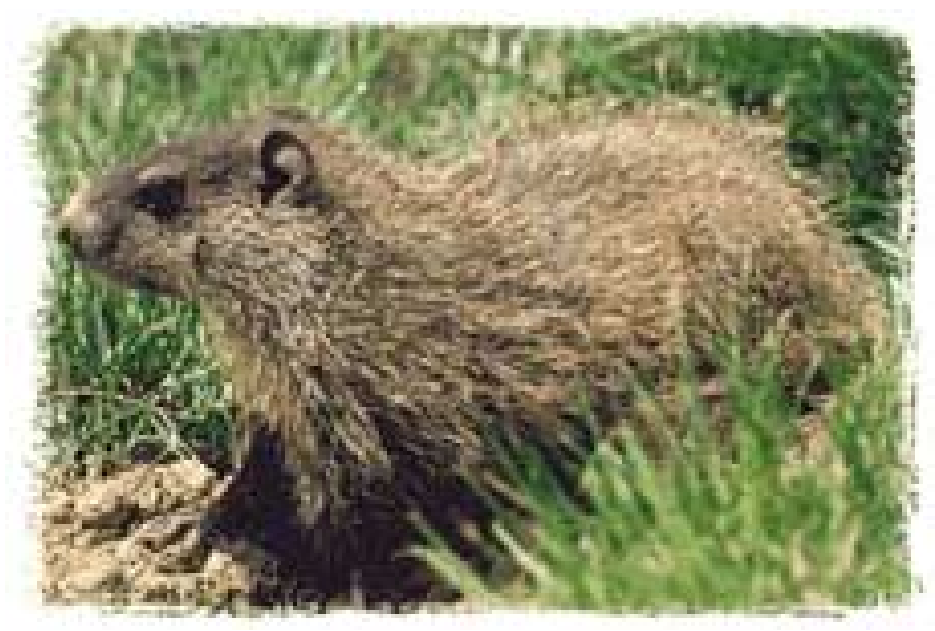

\section{Nuisance Concerns}

The woodchuck is a common burrowing mammal on the ORR. They are present around buildings on the ORR and will burrow under them. The mounds of dirt and holes that result from their burrowing can create tripping hazards and safety concerns for lawnmowers and other equipment. Burrows have occasionally resulted in the weakening of foundations. Woodchucks will occasionally gnaw on underground cables and rubber hoses in vehicles. They can also damage vegetation by gnawing (USDA 1994).

\section{Remedies}

The installation of horizontal footing extensions or wire-mesh curtain walls that extend a minimum of 12 in. $(30 \mathrm{~cm})$ below ground can be a good deterrent around buildings. Bending the lower edge of the wire-mesh curtain outward from the building in an L shape and burying it 2 in. $(5 \mathrm{~cm})$ under the ground will have the same effect (USDA 1994).

\section{Removal Methods}

Livetrapping of woodchucks and removal can be effective where the animals are already established. Traps should be located at main burrow entrances or in main travel lanes that might be visible on the ground surface out from the burrow. Traps can be baited with apple slices, vegetables such as carrots and lettuce, rodent food, or vegetable items coated with molasses (USDA 1994).

Live traps can be obtained from the TWRA wildlife manager. The wildlife manager can also provide advice on baiting and the size of trap to use. Once the animal is trapped, TWRA will complete its removal. The employee should not handle the animal in any way because of the 
possibility of disease. TWRA wildlife managers are trained to handle these animals and are properly vaccinated against disease.

\section{Disease Concerns}

Disease is not a great concern with woodchucks. Rabies cases are extremely rare in this species.

\subsubsection{Gray Squirrels}

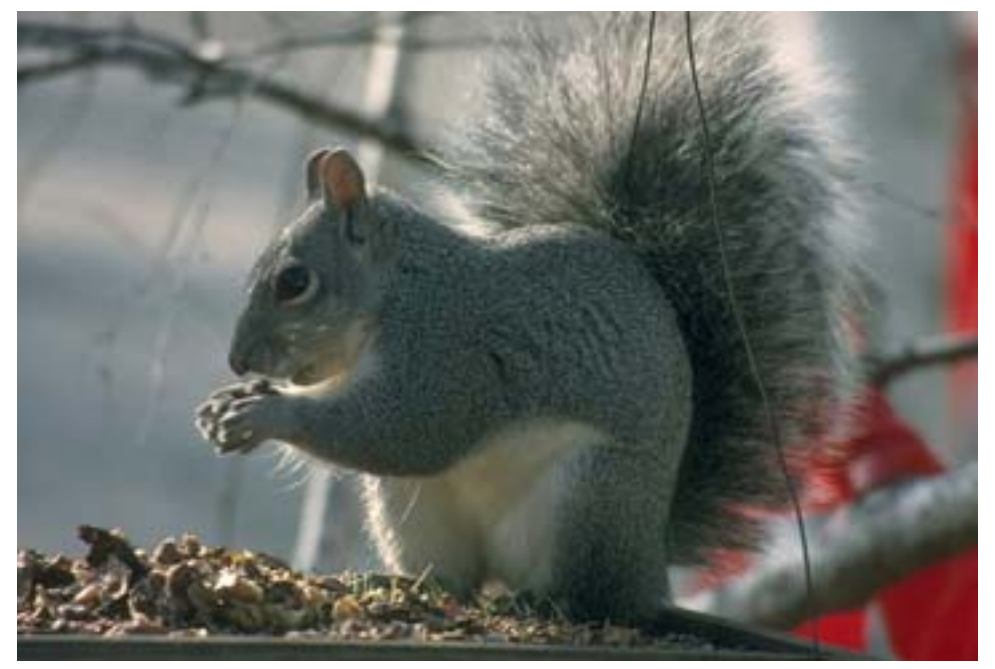

\section{Nuisance Concerns}

Gray squirrels are commonly found in close association with people. These animals quite commonly enter building attics, where they will build nests and gnaw on wires. They will gain access through broken vents or other openings where things are in disrepair. As do raccoons, they will commonly gain access to roofs by means of overhanging tree branches. Gray squirrels are also very skillful at walking along electrical wires and can gain access using this route (USDA 1994).

\section{Remedies}

The main prevention against gray squirrels is to seal all holes and keep all roof vents and soffits in good repair. As with other animals in attics, caution should be taken not to close animals inside. Squirrels, in particular, will attempt to gnaw their way out. One-way doors have been effectively used to prevent reentry into attics. It is important to note that squirrels will have young both in the February-March and July-August timeframes (Chapman and Feldhamer 1982). Added caution should be taken during these times to avoid trapping the young inside.

Squirrels can be prevented from climbing isolated trees and power poles by encircling the objects with a 2-ft-wide (61-cm-wide) collar of metal $6 \mathrm{ft}(1.8 \mathrm{~m})$ off the ground. In addition, they can be discouraged from traveling on wires by installing 2-ft $(61-\mathrm{cm})$ sections of lightweight 2- to 3-in.diameter (5.1- to 7.6-cm-diameter) plastic pipe. The pipe should be split lengthwise, spread open, and placed over the wire. The pipe will rotate on the wire, causing the squirrel to fall (USDA 1994). 


\section{Removal Methods}

Gray squirrels can easily be livetrapped using slices of orange and apple, walnuts or pecans removed from the shell, and peanut butter (USDA 1994). Traps can be placed in attic areas after all holes have been closed as an added precaution in case animals are still inside.

Live traps can be obtained from the TWRA wildlife manager. The wildlife manager can also provide advice on baiting and the size of trap to use. Once the animal is trapped, TWRA will complete its removal. The employee should not handle the animal in any way because of the possibility of disease. TWRA wildlife managers are trained to handle these animals and are properly vaccinated against disease.

\section{Disease Concerns}

The main concern with gray squirrels is that they tend to carry numerous ectoparasites, such as ticks, mange mites, and fleas, which can cause insect pest problems inside buildings where squirrels have managed to gain access (Chapman and Feldhamer 1982). Gray squirrels are usually relatively free of bacterial and viral agents. They will occasionally exhibit external tumors caused by a virus, which is not harmful to humans.

\subsubsection{Bats}

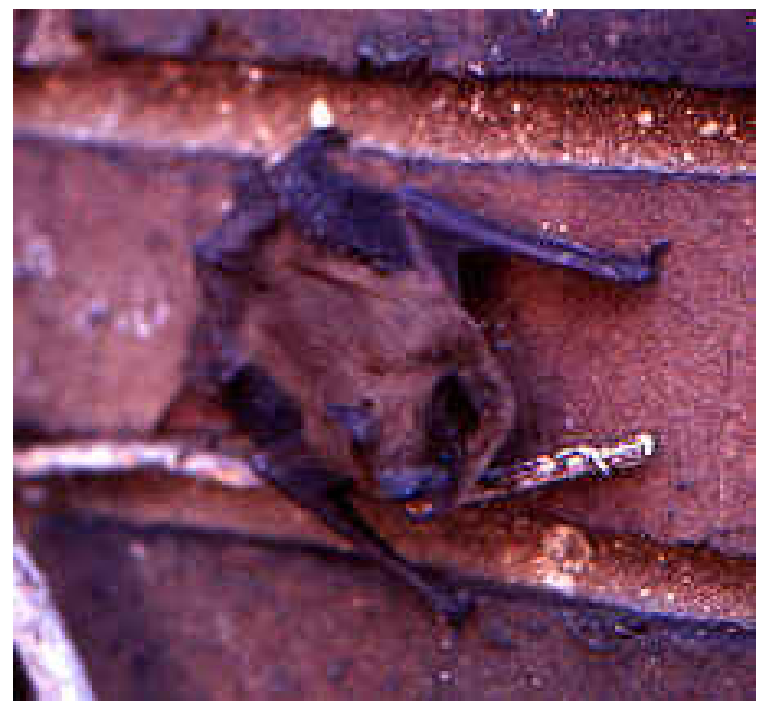

\section{Nuisance Concerns}

Bats commonly enter buildings through openings associated with the roof edge and valleys, eaves, apex of a gable, chimney, attic or roof vent, dormers, and siding. They can also use openings under loose-fitting doors and around windows, gaps around various conduits (e.g., wiring, plumbing, air conditioning) that pass through walls, and utility vents to gain access. Bats are able to squeeze through narrow slits and cracks (USDA 1994). They will also take advantage of a variety of indoor roosting sites in buildings and warehouses. 


\section{Remedies}

The most important preventative measure is again exclusion. Implementation of this remedy can be more complicated than for other species, however, because bats will find very obscure holes through which to gain entry. All gaps of $1 / 4$ by $11 / 2$ in. $(0.6$ by $3.8 \mathrm{~cm})$ and openings $5 / 8$ by $7 / 8$ in. (1.6 by $2.2 \mathrm{~cm}$ ) or greater should be sealed (USDA 1994). Ideally, this step should be taken during the time of year when bats are not present (usually September through March) or at night when bats leave to forage. Care should also be taken not to trap flightless young in buildings (generally present May through July) (Chapman and Feldhamer 1982).

Wildlife officials should be contacted prior to attempting to handle any bat problems because of the potential for the presence of endangered Indiana bats or gray bats.

\section{Removal Methods}

When bats enter the living space, the best means of removal is to confine the animal to one room and open any doors and windows, which will allow the bat to escape on its own. If this approach is not feasible, bats can be captured fairly easily using a hand (e.g., butterfly) net and released outside (USDA 1994). Heavy gloves should be used at all times when working with bats. If there is any concern about dealing with bats in this situation, either the TWRA wildlife manager or ORR Wildlife Management Coordinator can be called for assistance.

\section{Disease Concerns}

The existence of roosting bats is clearly indicated by the presence of droppings (i.e., guano). Bat droppings tend to be segmented, elongated, and friable. When crushed, they become powdery and reveal shiny bits of undigested insect remains. In contrast, mice and rat droppings tend to taper, are unsegmented, are harder and more fribrous, and do not become powdery when crushed (unless extremely aged) (USDA 1994). Bat guano can provide a growth medium for microorganisms, some of which are pathogenic to humans. One example is Histoplasma capsulatum, a microscopic fungus that can cause the respiratory disease histoplasmosis in humans. Therefore, extreme caution should be taken in any areas with large accumulations of bat guano. Respiratory protection might be required in such areas (Harper, Byford, and Dixon 2003).

Bats will occasionally carry rabies. Abnormal behavior by bats, such as being active during the day or lying on the ground incapable of flight, suggests that the bat could be rabid. These animals should be avoided and not handled in any way. If a bat does bite someone, that bat should be captured, if possible, without damaging the head and kept for analysis. ORNL Medical should be contacted immediately for treatment of the individual bitten. The ORR Wildlife Management Coordinator or TWRA wildlife manager should be contacted to capture the bat for testing. USDA, APHIS-WS will analyze the animal for rabies.

\subsubsection{Rats and Mice}

\section{Nuisance Concerns}

The control of rats and mice is a specific concern because they can carry a variety of diseases that may be transmitted to humans.

Rats and mice are extremely prolific and can exist in very high densities. The average female rat has four to six litters per year and can successfully wean 20 or more offspring annually. Summer mouse populations can reach as high as 15 mice per acre (37 per hectare). Their home ranges are relatively small (i.e., 1.2 to 3.7 acres [0.5 to $1.5 \mathrm{ha}$ ]) compared to those of larger mammals

(USDA 1994). 


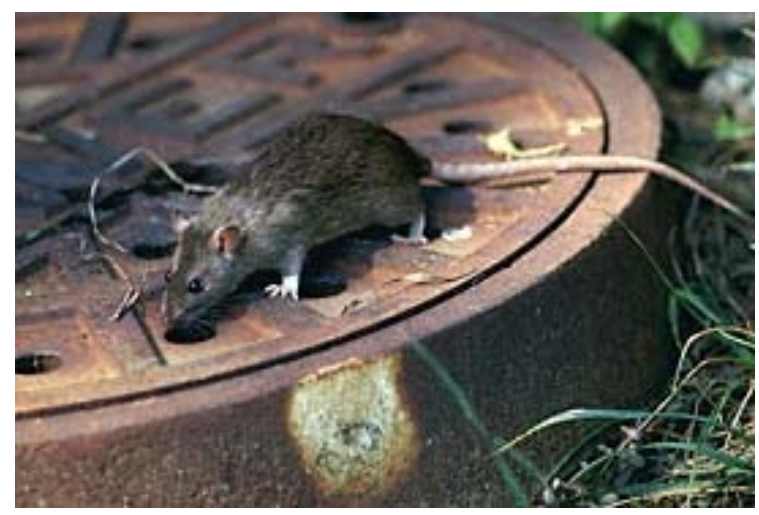

Norway Rat

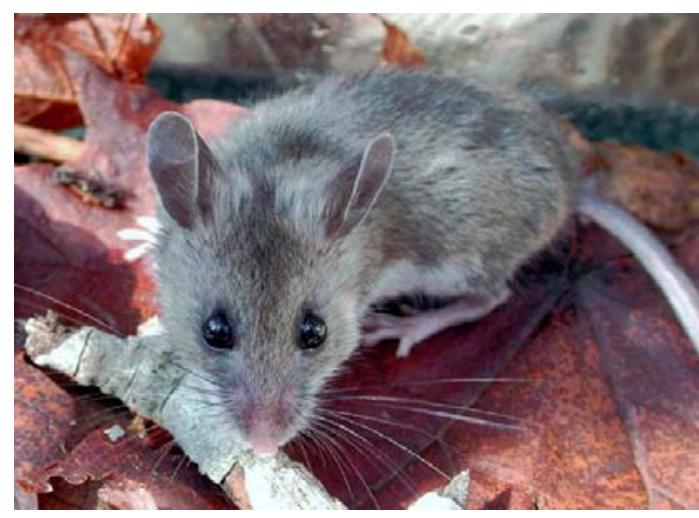

Deer Mouse

Rats can cause a wide range of problems for people. They will readily take advantage of any food that is left out. They can also cause structural damage to buildings with persistent burrowing and gnawing activities. Rats will also gnaw on electrical wires and piping. They are very capable of gaining access to buildings by gnawing through doors, window sills, walls, ceilings and floors. Considerable damage to insulated structures can occur as a result of rats burrowing and nesting in walls and attics (USDA 1994).

White-footed mice have a tendency to enter buildings that are not rodent-proof. Many times they will enter buildings in the colder months to seek warm shelter and food. They can cause considerable damage to upholstered furniture, clothing, paper, or other materials that they find suitable for their nest building activities and will leave ample signs with their nests and droppings. They also have a tendency to cache food supplies such as acorns, seeds, or nuts (USDA 1994).

\section{Remedies}

Physical barriers can prevent rats from entering structures. "Rat-proofing” is a very important part of rat control. To exclude rats, seal all holes and openings larger than $1 / 2$ in. $(1.3 \mathrm{~cm})$ across. Rodent-proofing should be done with heavy materials that will resist rodent gnawing. These materials include concrete mortar, galvanized sheet metal, and heavy-gauge hardware cloth. Sanitation and good housekeeping, including proper storage and handling of food, feed, and edible garbage, are very important preventative measures (USDA 1994).

As with rats, rodent-proofing is a good method for preventing mice from entering buildings. All openings larger than $1 / 4$ in. $(0.6 \mathrm{~cm})$ should be sealed. Mice will tend to gnaw small holes into larger ones to gain access. Sanitation and good housekeeping are again effective ways to reduce the presence of mice (USDA 1994).

\section{Removal Methods}

If rats do become a problem, there are numerous rodenticides available that are very effective on rat infestations in a variety of situations. The use of bait stations (bait boxes) can increase both the effectiveness and safety of rodenticides. Bait stations are useful because they protect the bait from moisture and dust, provide a protected area for rodents to feed, keep other animals and children away from hazardous bait, allow placement of bait in locations that would otherwise prove difficult because of weather or potential hazards to nontarget animals, and allow for easy inspection of bait to see if rodents are feeding on it. Trapping can also be an effective method of removing rats, although it can 
be labor intensive and requires more skill. The typical snap trap baited with a small piece of hot dog, bacon, or nutmeat can be effective where only a few rats are present (USDA 1994).

Rodenticides can also be used for mice. Small snap traps baited with cheese, peanut butter, or moistened oats can also be effective when trying to eliminate a few pesky mice (USDA 1994).

Live traps can also be used to capture rats and mice using bait similar to that used in snap traps. Live traps can be obtained from the TWRA wildlife manager. The wildlife manager can provide advice on baiting and the size of trap to use. Livetrapping of these small rodents is not normally recommended, unless for research, because overall population control of these very prolific rodents is typically the main goal. Release of these animals in other locations will most likely just move the nuisance somewhere else and could spread disease into other rodent populations.

\section{Disease Concerns}

The main disease concern is hantavirus. Infected rodents shed this virus in their saliva, droppings, and urine. Humans are infected when they inhale microscopic particles from the droppings and urine, which can result in hantavirus pulmonary syndrome (HPS), which causes the lungs to fill with fluid and can result in respiratory failure. Areas with high concentrations of rodent droppings hold the potential for the presence of hantavirus. There have been no recorded cases of HPS in the state of Tennessee, and there have been only isolated cases in surrounding states. The vast majority of cases have been in the western states.

\subsubsection{Beavers and Muskrats}

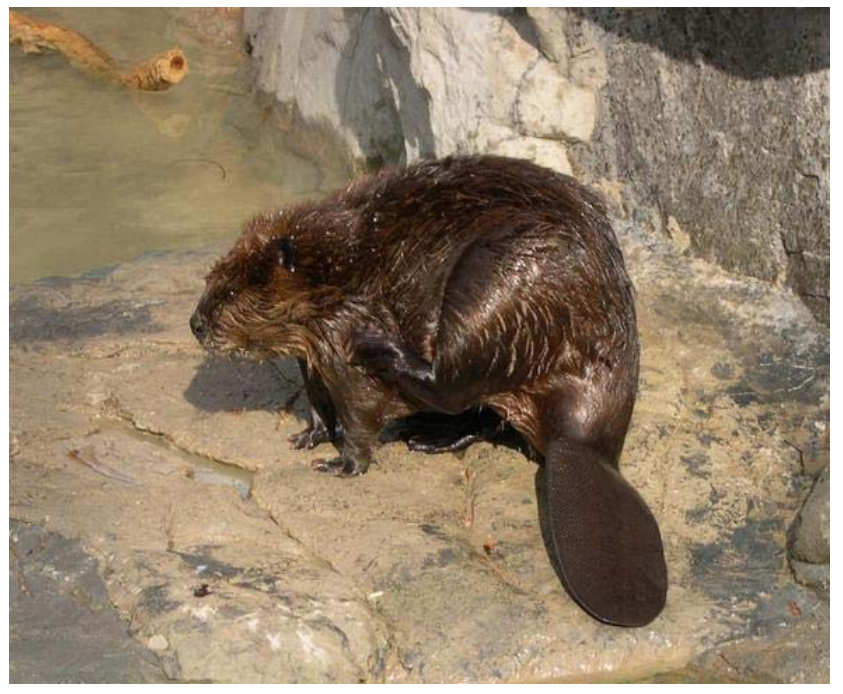

Beaver

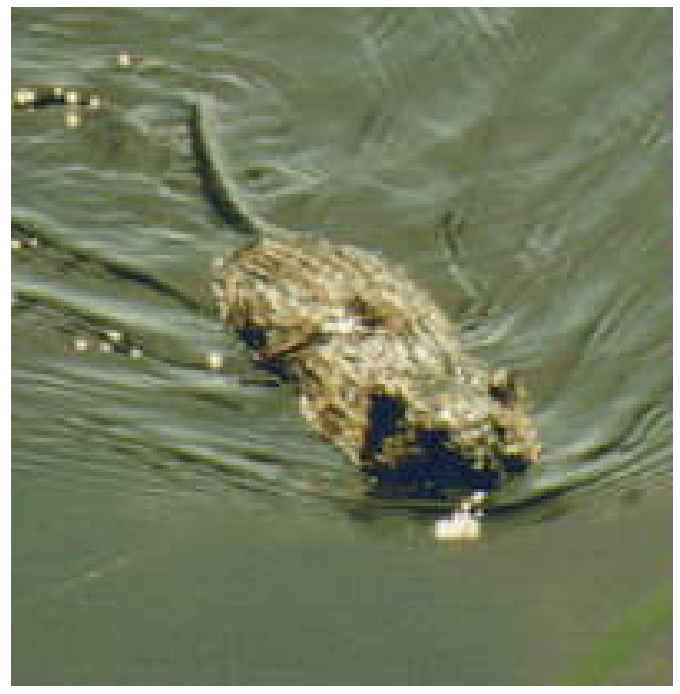

Muskrat

Beaver and muskrat control and trapping are specialized skills. Therefore, the TWRA wildlife manager will handle beaver- and muskrat-control measures in the ORNL ponds and along the watercourses, as necessary. In general, beaver-control measures will be taken in situations in which dams are creating flooding concerns or associated nuisance problems. Muskrat-control measures are typically taken where their burrowing activities alter stream flow or impact water levels in natural or manmade ponds. Only the TWRA wildlife manager will undertake beaver- and muskrat-trapping and -removal activities. The removal of dams and other debris resulting from beaver activity or repair of damage done by muskrat burrowing will be the responsibility of the appropriate ORNL F\&O personnel. 


\subsection{BIRDS}

There are several species of birds on the ORR that can cause nuisance problems because of their close association with humans. However, because most bird species are protected from harm by federal and/or state laws, caution must be taken in addressing certain bird nuisance problems.

\subsubsection{Vultures}

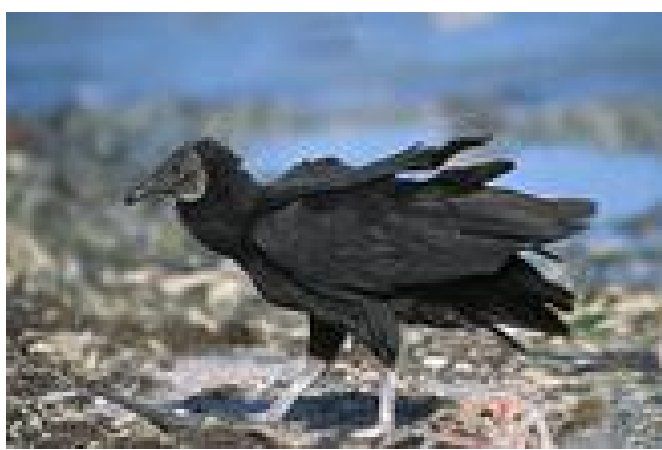

Black Vulture

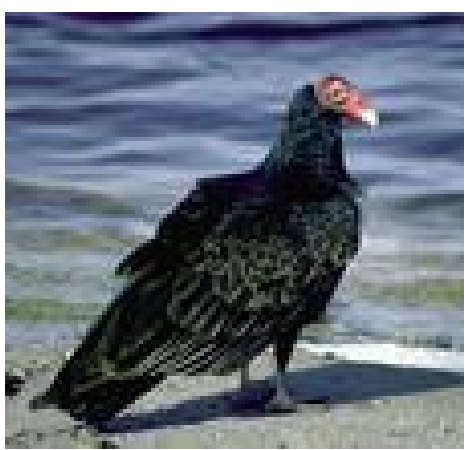

Turkey Vulture

\section{Nuisance Concerns}

Two species of vultures frequent the ORR: the black vulture and the turkey vulture. The black vulture is the most common and is distinguished by its black head, smaller size, and noticeable white wing tips when in flight. The larger turkey vulture has a red head as an adult, its wings have silver linings that show in flight, and it holds its wings in a shallow "V" while flying (Alsop 2001; National Geographic Society 2002).

The main nuisance concern with vultures involves their propensity to roost in high concentrations in certain areas, which results in large amounts of droppings. Large accumulations of droppings can cause unpleasant odors and impact an area aesthetically. It can also result in arcing where vultures roost on power-line towers. Black vultures, in particular, will also destroy property by ripping up roofing, caulking, and other rubberized materials.

Vultures can also nest in abandoned buildings were they will occasionally interfere with renovation and demolition projects.

\section{Remedies}

Exclusion methods such as installation of metal protectors or porcupine wires, particularly along building ledges, can be effective at vulture roosting sites. Tightly stretched parallel strands of steel wire or strong monofilament line can also discourage birds from roosting in certain locations.

Harassment can be an effective tool in displacing vultures from an area. To be effective, however, harassment must be persistent and initiated as soon as the problem is recognized. The implementation of several harassment tools at the same time will increase the likelihood of success. To effectively disrupt a roost, harassment should begin at dusk and continue until dark. Vultures should also be harassed at dawn and throughout the day if still present at the site. Harassment might need to continue for an extended period of time (i.e., weeks) to permanently displace the birds.

Harassment tools include electrified tracks, cylindrical rolling perches, motion-activated sprinklers, noise-making devices, flashlights, and water spray. Tactile devices, such as sticky repellents and double-sided tape, can also be effective in certain loafing locations; however, these must be employed carefully because sticky repellents tend to discolor painted, stained, or natural 
wood. These substances will also melt and run down the sides of buildings in warm weather, leaving visible streaks.

The hanging of effigies (i.e., dead vultures) in roosting areas has been successful in dispersing birds from certain areas. This tactic is typically accomplished by harvesting one vulture (which must be done under a federal permit) and then suspending the carcass from a tree or other structure where the birds are roosting at night. Doing so will help disperse the remaining birds from the area. The carcass should be placed as high as possible and as close to the roosting colony as practical.

(Commercially available artificial likenesses are also available.)

Specialized harassment techniques would typically be employed under the direction of USDA, APHIS-WS because they have the proper equipment and permits.

\section{Removal Methods}

Vulture populations can be effectively reduced in site-specific cases through shooting. However, this lethal means of control requires that strict health and safety guidelines be followed. In addition, vultures are protected by federal law and permits from the U. S. Fish and Wildlife Service (USFWS) are required. USDA, APHIS-WS has extensive experience with this method and also holds the proper permits to implement lethal techniques where necessary.

Vultures can be trapped using large walk-in traps with decoys. This technique can be an effective method when used in combination with others.

\section{Disease Concerns}

Vultures roosting on water towers can result in high concentrations of droppings being deposited in public water supplies, raising fecal coliform levels.

\subsubsection{Canada Geese}

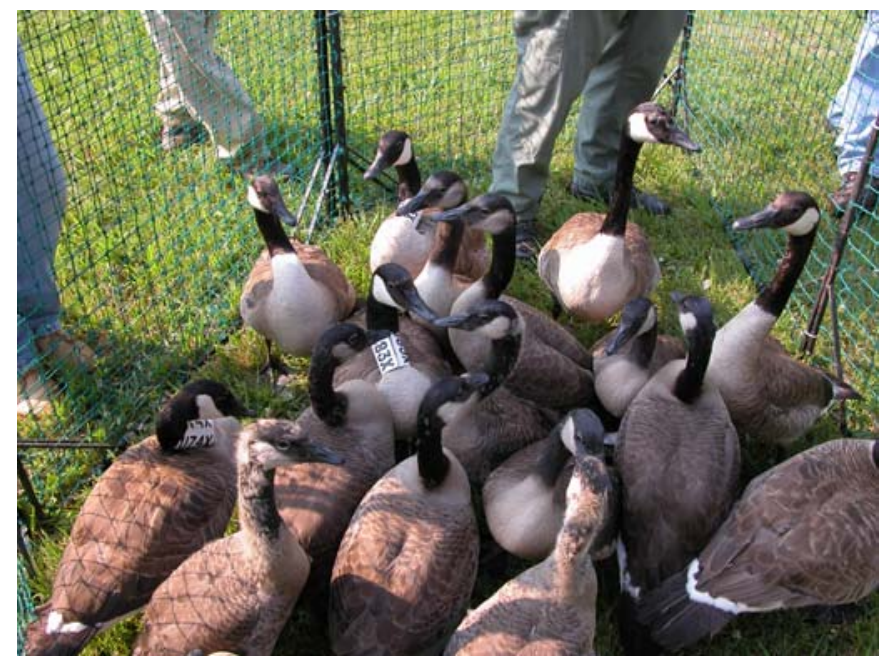

\section{Nuisance Concerns}

Canada geese are common at ORNL in areas of mowed turf grass, especially where these areas are associated with ponds and other water bodies. These geese are protected by federal law as migratory birds. However, yearly hunting seasons are conducted for the harvesting of these birds. In addition, federal permits can be obtained to deal with nuisance situations. Such situations typically involve resident populations of Canada geese that have lost their urge to migrate back to northern 
climates. This change mainly results when the geese are finding more-than-adequate nesting and feeding areas in these locations. Prime goose habitat has inadvertently been provided by humans with the creation of golf courses and other large, mowed turfgrass areas. Geese are grazers and show a clear preference for tender, mowed, and fertilized turfgrasses. Adjacent water bodies increase the appeal of these areas because they provide an important escape route from predators.

The presence of geese in mowed areas around buildings puts them in direct conflict with people. The main nuisance issues associated with large concentrations of geese in these areas are the presence of dropping on sidewalks and parking lots and aggression toward people. The problem is compounded by the fact that geese are very mobile, allowing them to quickly move to other areas when chased from one particular location. This mobility also presents the potential that geese will return to a location, even after capture and relocation to other areas of the state.

Canada geese will be present as long as mowed turfgrasses are maintained around buildings and facilities. The major nuisance for employees is goose droppings that will most definitely be left on sidewalks. Sidewalks should periodically be washed off to minimize this nuisance to the maximum extent possible. Employees need to be aware that geese can occasionally be aggressive, especially during the nesting season (March through May) (Nicholson 1997). Geese should especially be given plenty of room during the breeding season.

\section{Remedies}

Nuisance Canada goose concerns will be handled by the ORR Wildlife Management Coordinator and the TWRA wildlife manager. A multifaceted management approach has been established to handle Canada goose nuisance wildlife concerns at ORNL.

ORNL has implemented a "no feeding" policy to avoid having large numbers of geese in a relatively small area, which leads to high concentrations of dropping, and increased health and safety concerns. This policy has been successful in decreasing goose populations in certain areas of ORNL, particularly around the east campus pond.

Steps are being taken to reduce the number of areas of mowed turfgrasses through the implementation of native-species plantings and other habitat modifications. An important aspect of these changes includes the creation of physical barriers that limit line of sight. Geese become nervous and insecure when obstructions decrease their line of sight in search of potential predators and other dangers.

Various harassment techniques have been evaluated and might be used on occasion to resolve nuisance problems that occur at specific locations.

\section{Removal Methods}

ORNL holds a goose depredation permit from the USFWS that allows for the addling/oiling of eggs and the destruction of nests in situations in which geese become a nuisance. The other main population-reduction method used at ORNL is the relocation of geese from ORNL to other areas of Tennessee or to the Three Bend Scenic and Wildlife Management Refuge Area (the Three Bend Area) where suitable goose habitat is being established. Geese are rounded up in June during their flightless period for transport to other areas.

A goose hunt was established in 2006 at the Three Bend Area as an additional method of population control. The hunt allows for the potential harvesting of nuisance birds moved to that area during the June roundup, thereby providing an added measure in reducing the number of problem geese.

All goose population-control activities are led by the ORR Wildlife Management Coordinator in cooperation with the TWRA wildlife manager and USDA, APHIS-WS. 


\section{Disease Concerns}

The main disease concerns associated with the presence of high concentrations of Canada geese are results of the abundant droppings they produce, which can lead to excessive nutrient loading in ponds. The droppings can significantly elevate fecal coliform levels in water bodies in certain areas. The droppings can also carry other pathogenic bacteria and should be avoided to the maximum extent possible. Also, although avian flu is not currently a concern in the United States, such droppings could result in its spread through the goose population, to other birds, and potentially to humans if it does become an issue.

\subsubsection{Swallows}

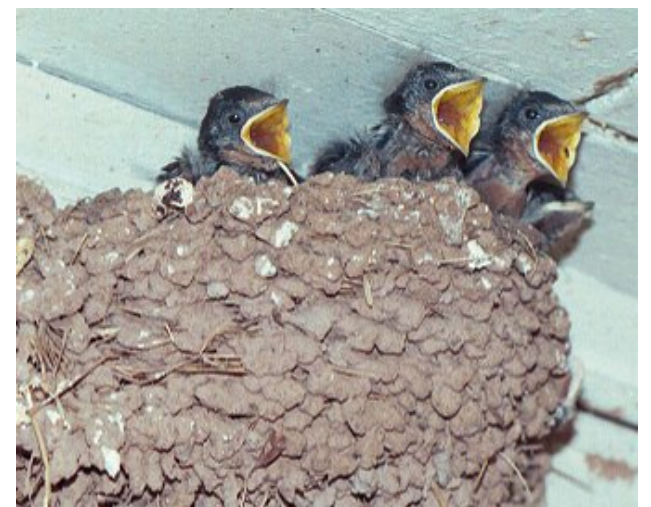

Barn Swallow Young in Nest

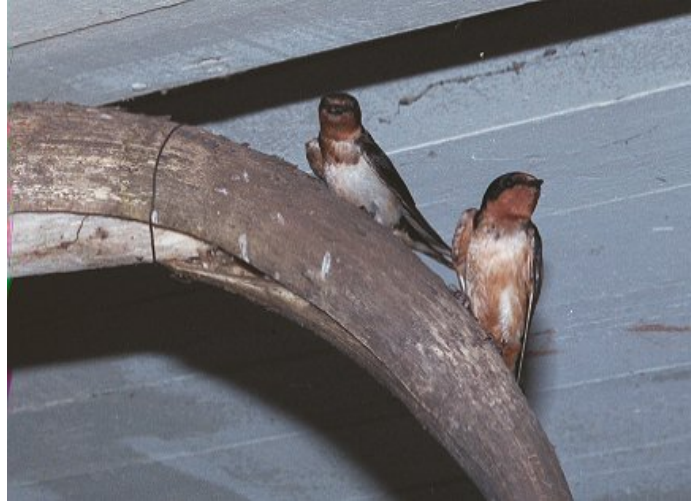

Barn Swallow Adults

\section{Nuisance Concerns}

Several species of smaller birds construct mud nests in and around buildings at ORNL. Two species commonly found on the ORR are the barn swallow and the cliff swallow.

Barn swallows typically build their nests on a ledge or vertical wall, or in the corner of two vertical walls, a short distance below a horizontal surface. On smooth concrete or painted surfaces, the nests are often placed on mud-dauber nests. Their nests are cup-shaped and constructed of pellets of mud and pieces of straw and are lined with feathers (Nicholson 1997). Cliff swallows nest in dense colonies, and hundreds of nests might occupy the side of a barn. The nests are gourd-shaped and built from pellets of mud and clay. Their nests are plastered to the sides and under the eaves of buildings (Harrison 1975).

\section{Remedies}

The most effective method of swallow control is exclusion from potential nesting sites. Plastic netting or poultry wire mounted on buildings from the outside edge of the eave down to the side of the building can be very effective. Panels made of fiberglass or other materials mounted under eaves to form a concave (rounded) surface can also work. Barn swallows, in particular, will enter buildings through doors, windows, or other entryways. They will seek nesting sites among the rafters in the buildings; therefore, it is important to keep entryways closed to buildings in which swallows could be a problem. For buildings to which doors need to remain open for extended periods of time for equipment passage and such, vinyl-plastic strip doors can be effective (USDA 1994). Swallows will tend to frequent buildings or warehouses that are infrequently used and/or have open access through broken windows or doors. These entryways should be sealed to prevent entrance. However, caution should be taken during the breeding season because birds could be trapped inside. To avoid this 
possibility where birds are known to be nesting, procedures for closing entryways should not be undertaken from late April through June.

\section{Removal Methods}

Nest removal can be conducted in the early stages of nest building with the use of a hose, broom, or other similar method. Persistence is the key during this process because the birds might attempt to rebuild several times. Eventually the birds will abandon the area to find a more suitable location. It is important to concentrate any nest destruction on the early stages of nest building because both barn and cliff swallows are protected against harm by federal law. This protection means that nesting swallows cannot lawfully be disturbed once in the process of laying and incubating eggs. Swallow young will fledge from the nest within 15 days of hatching, so another option would be to wait until the young have fledged and then take action (Harrison 1975). Once the young have fledged, nests can be knocked down, and permanent remedies can be undertaken. These swallows can have two sets of young in a year; therefore, the timing of the action can be critical to ensuring that the birds don't renest. If it is necessary that birds be removed during their nesting stage because of health and safety concerns, the ORR Wildlife Management Coordinator or TWRA wildlife manager should be contacted for assistance.

\section{Disease Concerns}

Disease is not considered to be a major issue with swallows. However, gloves and dust masks should be worn during nest removal to guard against any ectoparasites or airborne particles that might be present in the nesting material.

\subsubsection{European Starlings and House Sparrows}

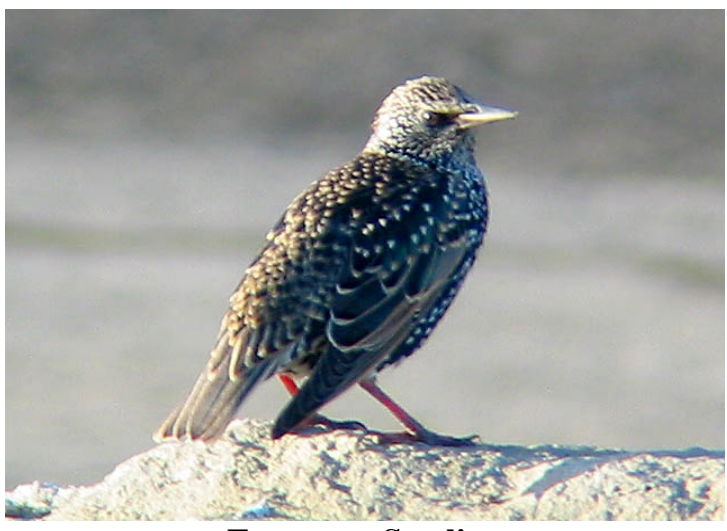

European Starling

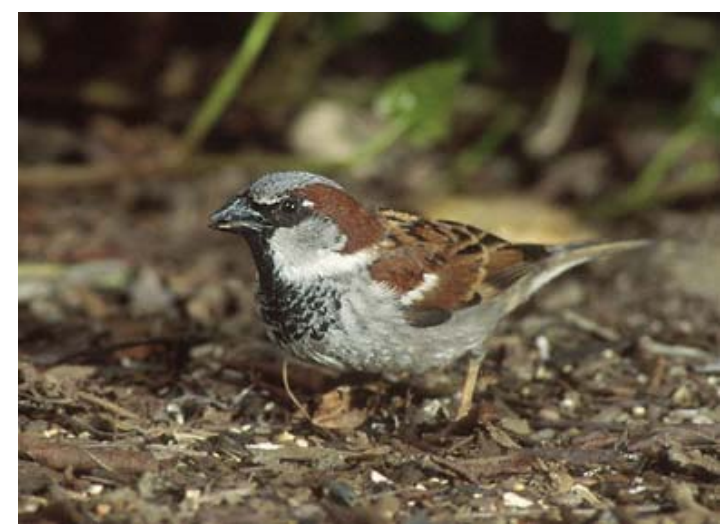

House Sparrow

\section{Nuisance Concerns}

European starlings and house sparrows are two other bird species typically found in close association with people. Both of these species find suitable nesting sites in buildings where open access is afforded by holes in walls, broken vents, doors, and windows. Starling nests are a mass of grasses and weed stems with a cup at the top. These birds will build their nests wherever holes are associated with internal cavities in walls, ceilings, under eaves, in light poles, etc. House sparrows will choose similar nesting sites. Sparrows construct partially roofed nests of grasses, straws, and weed stems lined with feathers. These nests will frequently fill the entire area of the cavity (Harrison 1975). 
Starlings also form large roosting groups in the winter months, resulting in large concentrations of droppings in certain areas.

\section{Remedies}

To prevent starlings from nesting in buildings, all openings more than $1 \mathrm{in} .(2.5 \mathrm{~cm})$ in diameter should be closed. Heavy plastic (e.g., polyvinyl chloride) or rubber strips hung in large, open doorways of warehouses and other buildings have been successful in excluding birds, while allowing people and machinery to pass through. Where starlings are nesting or roosting on building ledges, wooden, metal, or Plexiglas ${ }^{\circledR}$ covers can be placed to cover ledges at a $45^{\circ}$ angle to prevent use. ${ }^{1}$ Metal protectors or porcupine wires are also available for preventing roosting on ledges or roof beams. Nylon or plastic netting can also be used across the bottom of exposed beams and rafters to prevent use of those areas (USDA 1994).

Similar precautions are recommended to exclude house sparrows. All openings larger than $3 / 4$ in. $(1.9 \mathrm{~cm})$ should be closed. Glass should be replaced in broken windows and doors. Heavy plastic (e.g., polyvinyl chloride) or rubber strips hung in large, open doorways of warehouses and other buildings can also be effective with sparrows. As is the case with starlings, nesting or roosting on building ledges can be discouraged with the placement of wooden, metal, or Plexiglas ${ }^{\circledR}$ covers on ledges at a $45^{\circ}$ angle. Metal protectors or porcupine wires can again be used to prevent roosting on ledges or roof beams. Eaves should be screened if birds are able to squeeze into them. Spaces between window air conditioners and buildings should be blocked to keep sparrows out. House sparrows have a tendency to nest behind signs on buildings; therefore, all signs should be mounted flush with the building wall. In general, the manager should examine ventilators, vents, air conditioners, building signs, ledges, eaves, overhangs, and ornamental openings for potential and existing bird usage and eliminate those sites where practical (USDA 1994).

\section{Removal Methods}

Neither European starlings nor house sparrows are native to the United States, and they are considered to be mainly nuisance birds. For this reason, they are totally unprotected by any laws. Therefore, significant latitude can be taken in the removal of these birds from problem areas.

Toxicants are available to deal with house sparrows and starlings; however, they must be administered by a licensed applicator. USDA, APHIS-WS should be consulted for such applications. These species can also be livetrapped fairly easily. However, caution must be taken because nontarget species could be caught in the process. Care would need to be taken to ensure that nontarget species were released unharmed. Nest removal and destruction represent another viable method; however, persistence is required because birds might attempt to renest in the same area several times. Therefore, any nest-removal activities must immediately be followed by a solution that permanently closes that nesting location.

\section{Disease Concerns}

The concentration of starlings in large roosting groups during the winter months creates potential disease concerns. One of the more serious health concerns is the fungal respiratory disease histoplasmosis. The Histoplasma capsulatum fungus can grow in the soils beneath bird roosts, and spores can become airborne in dry weather, particularly when the area is disturbed.

\footnotetext{
${ }^{1}$ Reference herein to any specific commercial product, process, or service by trade name, trademark, manufacturer, or otherwise, does not necessarily constitute or imply its endorsement, recommendation, or favoring by the United States Government or any agency thereof or its contractors or subcontractors.
} 


\subsubsection{House Finch}

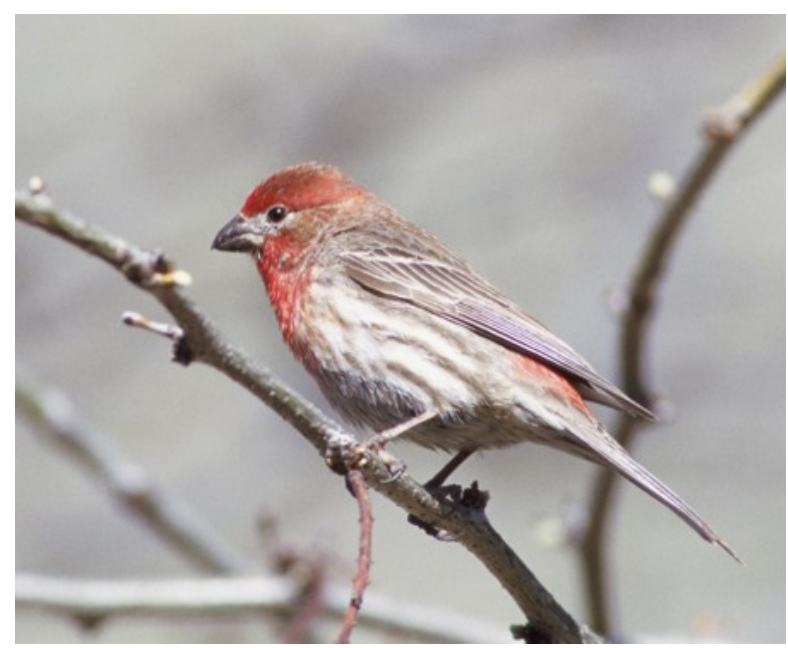

\section{Nuisance Concerns}

House finches are about the same size as house sparrows. Their nests are a mixture of twigs, grasses, various debris, and feathers. They will commonly nest on building ledges and in holes under eaves and soffits. They might sometimes be confused with house sparrows because of their size and general habits; however, the reddish head on the male is unmistakable.

\section{Remedies}

The house finch, unlike the house sparrow, is protected under federal law, which has an impact on the options available for the treatment of nuisance issues concerning this species. However, preventative measures similar to those recommended for starlings and house sparrows will also handle this species. Because of its protected status, any actions taken to resolve nuisance issues with this species should be first coordinated with the ORR Wildlife Management Coordinator or TWRA wildlife manager.

\section{Removal Methods}

The use of toxicants is typically not an option for this species because of its protected status. This species can be livetrapped fairly easily; however, caution must be taken because nontarget species might be caught in the process. Care would need to be taken to ensure that nontarget species were released unharmed. The removal of nesting material at the early stages of nest building is another viable method; however, persistence is required because birds might attempt to renest in the same area several times. Therefore, any nest-removal activities must immediately be followed by a solution that permanently closes that nesting location. House finch young will fledge from the nest within 12 to 14 days of hatching; therefore, another option would be to wait until the young have fledged and then take action (Harrison 1975). Once the young have fledged, nesting material can be removed, and permanent remedies can be implemented. These finches can have two sets of young in a year, so the timing of the action can be critical to ensuring that the birds don't renest. If it is necessary that birds be removed during their nesting stage because of health and safety concerns, the ORR Wildlife Management Coordinator or TWRA wildlife manager should be contacted for assistance. 


\section{Disease Concerns}

There are no significant disease concerns associated with this species. However, gloves and dust masks should be worn during nest removal to guard against any ectoparasites or airborne particles that might be present in the nesting material.

\subsubsection{Pigeon (Rock Pigeon)}

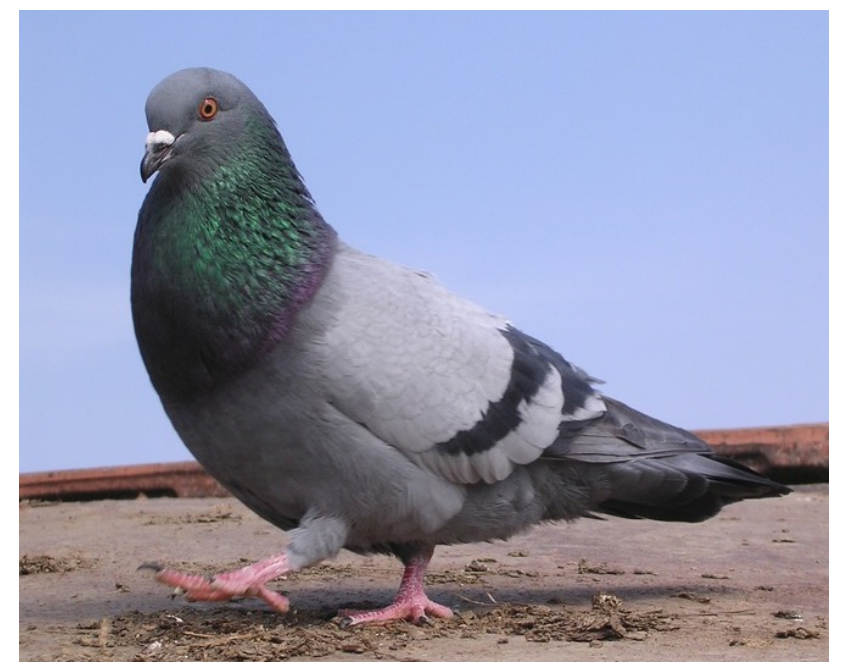

\section{Nuisance Concerns}

Pigeons are birds that are also usually found in close association with people. Typical nesting and roosting locations for these birds include any ledge or other platform to which they can gain access, usually in buildings or under bridges. They build a very crude nest of sticks and grasses.

Excessive droppings can become a great aesthetic problem on the outside of buildings and under bridges, where these birds can be highly concentrated. In addition, droppings can have a caustic effect, which defaces and can accelerate deterioration of building materials.

\section{Remedies}

Pigeons can be excluded by blocking entrances to indoor roosts and nesting areas. Openings to attics, vents, soffits, and eaves should be blocked with wood, metal, Plexiglas ${ }^{\circledR}$, or other sturdy building material. Entrances can also be blocked with 1/4-in. (0.6-cm) rustproof wire mesh or nylon netting. Where pigeons are nesting or roosting on building ledges, wooden, metal, or Plexiglas ${ }^{\circledR}$ covers can be placed to cover ledges at a $45^{\circ}$ angle to prevent use. Metal protectors or porcupine wires can also be effective in preventing roosting on ledges or roof beams. Nylon or plastic netting can be installed across the bottom of exposed beams and rafters to prevent use of those areas. Tightly stretched parallel strands of steel wire or strong monofilament line can also be effective in discouraging birds from roosting in certain locations. Electric-shock bird-control systems that use a cable and electrical conductors can also be considered in situations in which pigeons are persistent (USDA 1994).

Refraining from the feeding of nontarget bird species might need to be considered in certain cases where such feeding is attracting unwanted pigeons. 


\section{Removal Methods}

Lethal means of controlling pigeons can and have been used effectively. Avitrol ${ }^{\circledR}$ is an approved chemical frightening agent commonly used on pigeons. (Note: Avitrol ${ }^{\circledR}$ may be applied only by a certified pesticide technician with certification in the appropriate category.) It is typically applied in whole-corn bait. Birds that consume a sufficient amount of bait typically die. Distress behavior displayed by these birds before death will typically alarm other birds and scare them away from the area. Baits can be diluted to decrease mortality and increase alarm reactions (USDA 1994). It is critical that baiting stations be situated so as not to impact nontarget bird species. (Note: DRC-1339®) is another toxicant commonly used on pigeons by USDA, APHIS-WS. This toxicant may be applied only by USDA, APHIS-WS or under that agency's direct supervision.)

Alpha-chloralose is an immobilizing agent that can be used effectively on pigeons in certain situations. It is currently registered as an experimental animal-capture drug with the Food and Drug Administration. Pigeons are fed alpha-choralose during a highly controlled baiting program. The agent anesthetizes the birds, at which time they can be picked up for removal from the area. (Note: Alpha-chloralose may be applied only by USDA, APHIS-WS personnel.)

Pigeons can also readily be livetrapped with bait by their roosting, loafing, and feeding sites. Prebaiting is required for several days before actual trapping to draw birds into a relatively small area. Whole corn is typically used at bait sites; however, other seed (e.g., milo, sunflower) can also be used in cases in which the birds have been acclimated to such feeds around birdfeeders. The trap is then placed over the bait site. Typical traps are made of wire and have either funnel- or one-way-gate-type entrances. All trapped birds should be euthanized. Releasing birds back to the wild is not recommended because pigeons are likely to return even when released as far as 50 miles $(80.5 \mathrm{~km})$ away. Even if pigeons do not return, they could become a nuisance in another area (USDA 1994).

Nest destruction can also be a good method of pigeon control if it is done on a persistent basis. Pigeons are highly prolific and can breed year-round. This method is most effective when coupled with others.

\section{Disease Concerns}

Droppings can create health concerns because pigeons can carry a variety of diseases, including encephalitis, toxoplasmosis, and salmonella. In addition, droppings can carry airborne spores of histoplasmosis. Pigeons also harbor a variety of ectoparasites such as fleas, lice, and ticks (USDA 1994).

\subsubsection{Other Birds}

\section{Nuisance Concerns}

Some other bird species commonly nest where building design has created artificial nesting structures similar to those they find in natural areas. It must be remembered that the vast majority of bird species are protected from harm by federal and state laws. Therefore, all available options should be weighed prior to taking any action. It is important to realize that most small bird species fledge young within 2 weeks of hatching. This being the case, many of the nuisance concerns regarding these nesting birds will resolve themselves within a short period of time. After that time, measures (e.g., closing holes, modifying building design features) can be taken to resolve the concern for the long term.

The Carolina wren and the eastern phoebe are two protected bird species that commonly nest in and around buildings. 


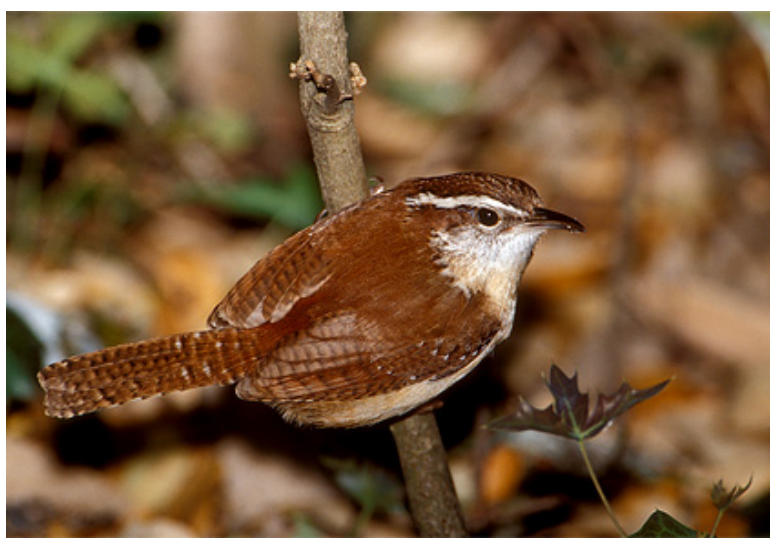

Carolina Wren

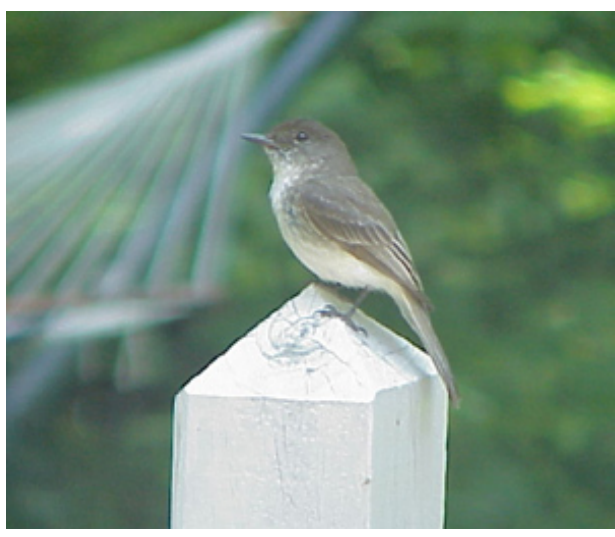

Eastern Phoebe

The Carolina wren has adapted extremely well to human habitation and will commonly nest in and around houses and other buildings. They will nest in tin cans, mailboxes, pipes, and on ledges in garages, warehouses, and outbuildings. They are persistent nest builders and might try to rebuild several times after the initial nest is destroyed.

The eastern phoebe will commonly nest on ledges in barns, warehouses, garages, and other buildings. They will essentially nest wherever a ledge is provided with sufficient overhead cover, including on window ledges and on top of light fixtures.

\section{Remedies}

Both the Carolina wren and eastern phoebe are protected from harm by federal law, which could have an impact on the options available for the treatment of nuisance issues concerning this species. However, preventative measures similar to those recommended for starlings, house sparrows, house finches, and pigeons will also handle this species. Because of their protected status, any actions taken to resolve nuisance issues with these species should be first coordinated with the ORR Wildlife Management Coordinator or TWRA wildlife manager.

\section{Removal Methods}

Removal of nesting material is a viable option if conducted during the early stages of nest building. Persistence is the key at this point, especially with regard to the Carolina wren because of its usual determination in building a nest in a certain location. Daily and sometimes twice-daily removal of nesting material might be required to discourage the birds from nesting in a particular area.

It is typically not recommended that nests be disturbed once eggs have been laid because of the protected status of these birds. Eggs will hatch within 14 to 16 days, and young will be out of the nest in an additional 14 to 16 days (Harrison 1975). If it is not unreasonable to wait this period of time for the young to fledge, doing so will allow for full protection of the birds. However, after the young have fledged, all nesting material should immediately be removed, and steps should be taken to eliminate that nesting location (i.e., structural modifications or other institutional controls should be employed). This step is particularly important for both the Carolina wren and eastern phoebe because they tend to nest twice in the breeding season. If it is required that birds be removed during their nesting stage because of health and safety concerns, the ORR Wildlife Management Coordinator or TWRA wildlife manager should be contacted for assistance. 


\section{Disease Concerns}

Typically no significant health concerns are associated with these bird species. However, gloves and dust masks should be worn during nest removal to guard against any ectoparasites or airborne particles that might be present in the nesting material.

\subsection{SNAKES}

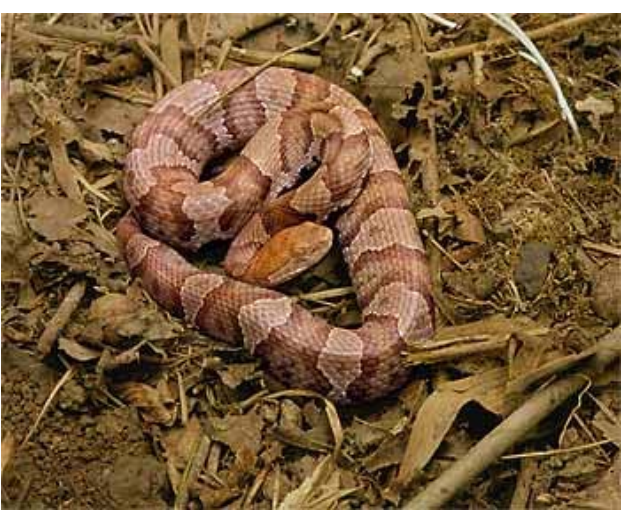

Northern Copperhead

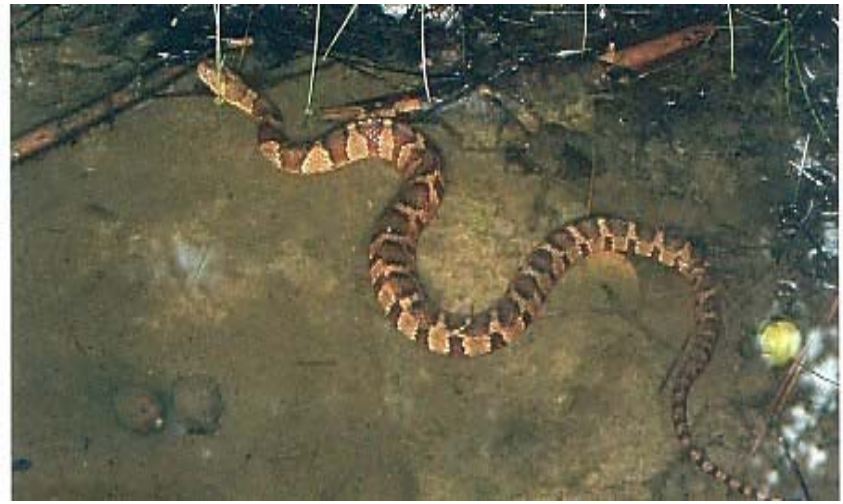

Northern Water Snake

\section{Nuisance Concerns}

Snakes serve a beneficial purpose in the environment in that they can effectively control rodent populations. Most snakes people will encounter at ORNL are totally harmless and would rather retreat than attack. Snakes are protected, and indiscriminant killing is illegal.

The copperhead is the only poisonous snake known to frequent ORNL. The copperhead is a pit viper and can be easily distinguished from nonpoisonous snakes by its elliptical pupils and face pits (located behind and below each nostril) (Conant and Collins 1998). Copperheads are also very heavy bodied, whereas other similar-looking snakes at ORNL tend to be slender in appearance. The main nuisance complaints involving snakes result from their presence around and in buildings.

\section{Remedies}

Snakes are capable of accessing buildings through any gap/hole that is approximately $1 / 4 \mathrm{in}$. $(0.6 \mathrm{~cm})$ or larger. So, first and foremost, all openings to the outside that are $1 / 4 \mathrm{in}$. $(0.6 \mathrm{~cm})$ or larger should be closed, when possible. In general, snakes will seek out cool, damp, dark areas where they can find food. They may be attracted to the outsides of buildings where there are low bushes and shrubs, rocks, boards, firewood piles, and debris lying on the ground. Anything that provides cover close to the ground can attract snakes (USDA 1994; Harper, Byford, and Dixon 2003). Therefore, if there is a snake problem, these types of settings should be evaluated when they occur in close proximity to buildings. Additionally, if there are any areas inside the building that could provide similar habitat (i.e., cool, damp, dark areas), the problem should be remedied wherever possible.

There are no registered toxicants or fumigants for snakes. Several repellents have been promoted, but none are consistently effective.

\section{Removal Methods}

For small, harmless snakes, the person can consider removing the snake from the premises himself or herself. Many of the smaller snakes found in buildings can be captured under a small trash 
can or similar container. After the snake is trapped under the trash can, the individual can slide a piece of cardboard or other material of similar strength and rigidity under the can. The remover can then lift the trash can holding the cardboard over the top opening and release the snake outside.

Glue boards can also be effective in the capture of snakes. Several rodent glue boards can be tacked to a piece of plywood to provide an effective surface area (at least 7 by 12 in. [17.8 by $30.5 \mathrm{~cm}]$ ) for the capture of passing snakes. The glue board should be placed against the wall, where snakes are likely to travel. Once captured and carried outside, snakes can be easily dislodged from the glue board using vegetable oil, which will neutralize the glue (USDA 1994; Harper, Byford, and Dixon 2003).

If the person feels uncomfortable capturing snakes, he or she can call the ORR Wildlife Management Coordinator for assistance. For nuisance problems involving large, nonpoisonous snakes or copperheads, the ORR Wildlife Management Coordinator should be contacted for assistance.

\section{Disease Concerns}

Some reptiles carry Salmonella. Therefore, it is recommended the gloves be used when handling any snakes. It is also a good practice to wash hands thoroughly after handling snakes, regardless of whether gloves are used.

\subsection{INSECTS}

\subsubsection{Fire Ants}

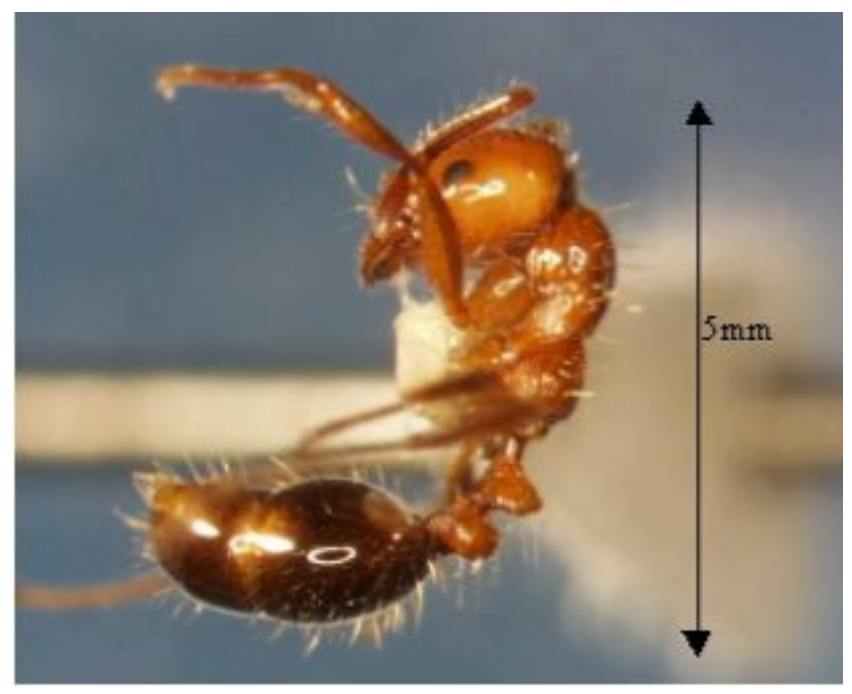

\section{Nuisance Concerns}

Imported fire ants have spread to such an extent in the southeast that the USDA established a quarantine program to hinder further spread of this insect. This quarantine impacts several southeastern states and counties. ORNL was recently added to this quarantine area. The transport of soils, plants, sod, baled hay/straw, and soil-moving equipment is strictly regulated in these areas. All nursery stock and other items are to be treated prior to transport from fire-ant-infested to fire-ant-free areas.

Imported fire ants are reddish-brown to black and are $1 / 8$ to $1 / 4$ in. $(0.3$ to $0.6 \mathrm{~cm})$ long. They construct nests that are often most visible as dome-shaped mounds of soil, sometimes as large as $3 \mathrm{ft}$ $(0.9 \mathrm{~m})$ across and $11 / 2 \mathrm{ft}(0.5 \mathrm{~m})$ in height. In general, mounds are $12 \mathrm{in.}(30.5 \mathrm{~cm})$ or more in 
diameter and height. In sandy soils, mounds are flatter and less visible. Fire ants usually build mounds in sunny, open areas such as lawns, pastures, cultivated fields, and meadows, but they are not restricted to these areas. Mounds or nests can also be located in rotting logs, around trees and stumps, under pavement and buildings, and occasionally indoors. Fire ants are most notable here at ORNL in sparse grassy areas and along sidewalks and curbs.

Fire ants can create a major nuisance because of their aggressive response to nest disturbance, which triggers attacks in large numbers. Upon attack they bite with powerful jaws and sting with a stinger on their abdomen.

\section{Remedies}

All fire ant mounds should be avoided and reported to Ernest Ryan, the ORNL Field Environmental Compliance Representative. He is responsible for recording the Global Positioning System locations and mapping fire ant mounds at ORNL. Fire ant mounds are typically treated with chemical pesticides by $\mathrm{F} \& \mathrm{O}$.

\section{Removal Methods}

Fire ant mounds are treated in place. Attempts to physically remove fire ants and/or their mounds can result in further range expansion of this insect, which is already rapidly spreading throughout the southeast.

\section{Disease Concerns}

There are no major disease concerns associated with fire ants. The main concern is the painful bites that they inflict. The wounds form red welts, followed in a day or two by the formation of blisters. Employees bitten by fire ants should report to ORNL Medical for treatment.

\subsubsection{Paper Wasps, Bald-faced Hornets, and Yellowjackets}
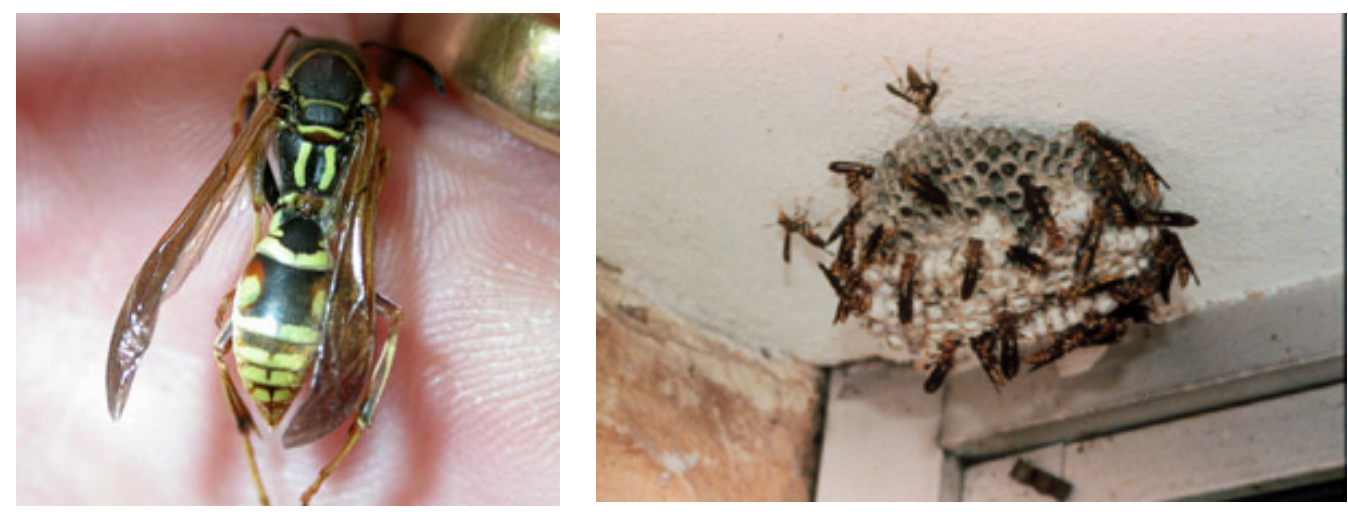

Paper Wasp 

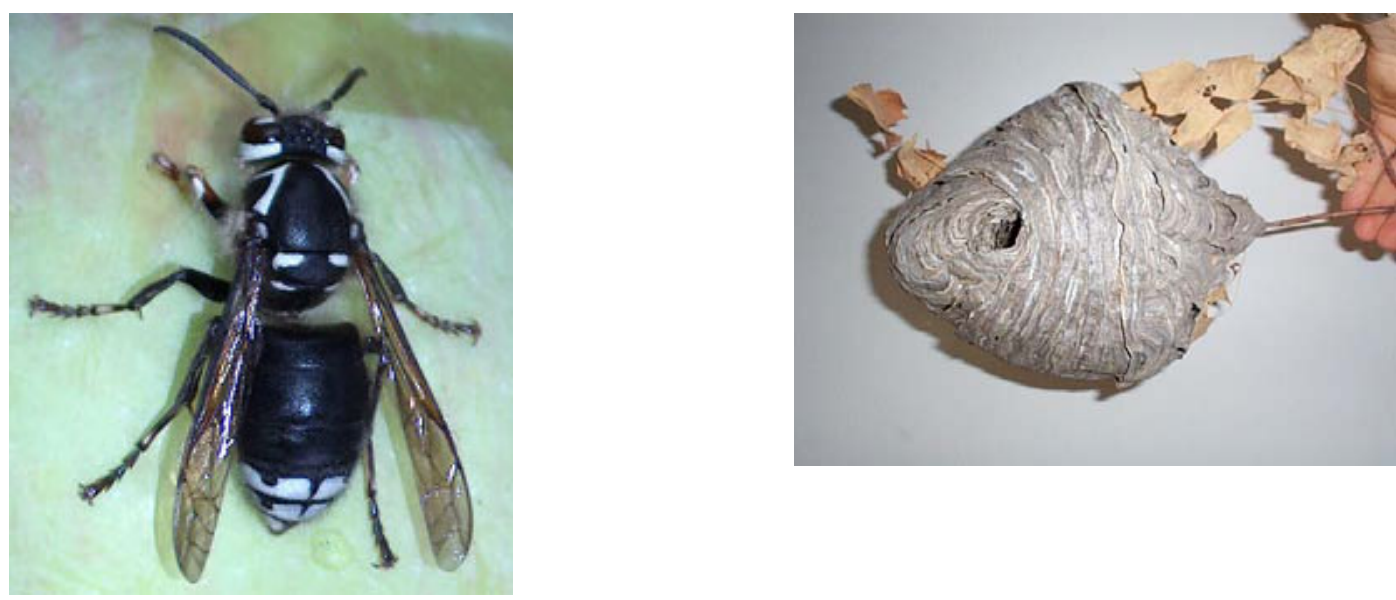

Bald-faced Hornet

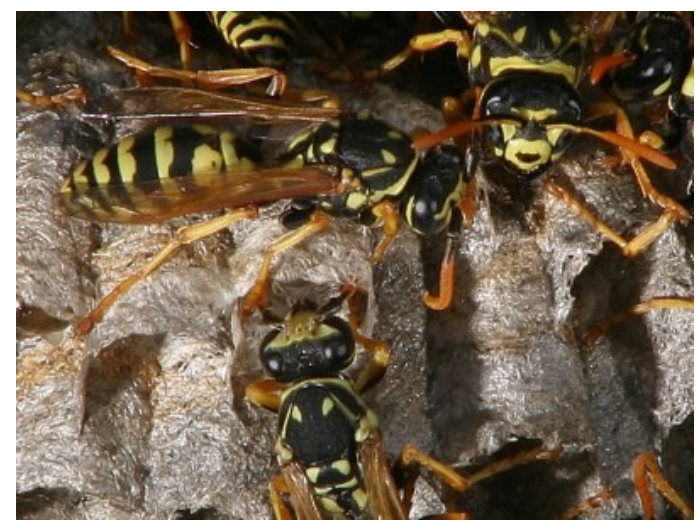

Yellowjacket

\section{Nuisance Concerns}

Paper wasps, bald-faced hornets, and yellowjackets are social wasps that construct their nests of paper-like material that is made up of a mixture of chewed wood fragments and saliva. Wasps, hornets, and yellowjackets actually serve a beneficial purpose because they will prey upon other insects that are considered pests. They can also serve as food for bears, skunks, birds, and other insects. Unlike honeybees, their colonies die out each year.

Paper wasps are slender wasps with long legs and a distinct slender waist. They build umbrellashaped nests under eaves and ledges.

Bald-faced hornets are large, black and white, heavy-bodied wasps approximately 3/4 in. $(1.9 \mathrm{~cm})$ long. They build rather large football- or basketball-shaped nests in trees and shrubs. They will also occasionally build nests under roof overhangs; in attics, crawlspaces, and walls; and under decks or porches.

Yellowjackets are house-fly-sized wasps with yellow and black markings. They also construct a paper-type nest, but it is typically built in an underground cavity. Common locations for nests are in lawns and at the base of trees or shrubs. Occasionally they will nest in attics and walls.

The main nuisance concern for these wasps is the painful stings that they can inflict when nests are disturbed. 


\section{Remedies}

Paper wasps, bald-faced hornets, and yellowjackets can generally be eliminated with over-thecounter wasp and hornet sprays. Applications are often most safely done at night when the insects are inactive and in their nests.

Paper wasps are not as aggressive as hornets or yellowjackets; therefore, their nests can be sprayed during the day with little risk of getting stung. Many sprays have a long-range stream (i.e., 10 to $20 \mathrm{ft}$ [3 to $6 \mathrm{~m}$ ]), which will allow the person to stand some distance away from the nest. It is recommended that the person not stand directly under the nest to keep wasps from dropping down and possibly stinging him or her (Potter 1994). This approach also minimizes the potential for the individual being hit by the spray.

Bald-faced hornet nests can also be effectively treated with over-the-counter insecticides. If the nest is built in a tree and not an immediate danger to people, consideration should be given to waiting and allowing the colony to die out in late fall or early winter. The nest will then slowly fall apart in the weather or be picked apart by birds. If the nest is in an area of immediate danger to people, then it should be eliminated. This remedy should be undertaken in the evening to avoid being stung because these hornets tend to be aggressive. Wasp and hornet sprays capable of spraying a long distance are effective. The spray should be directed through the opening in the bottom of the nest. This treatment might need to be repeated on subsequent evenings if activity is still noted. Treatment should not be conducted while shining a flashlight or other light directly into the nest opening because hornets will be attracted to the light. For nests that are located in walls, attics, and crawlspaces, professional extermination could be the best alternative (Bambara and Waldvogel 1999).

Yellowjacket nests can also be effectively treated with over-the-counter insecticides with long spray ranges if the nests can be located. If the nest is in an out-of-the-way location and not an immediate danger to people, consideration should be given to waiting and allowing the colony to die out in late fall or early winter. These nests can also be treated by drenching the entrance hole with insecticide and plugging the hole with treated cotton balls. Yellowjackets not killed by the initial treatment will be killed when attempting to chew their way out through the cotton balls. Treatment should again be conducted at night when the yellowjackets are inactive. If it is an underground nest, the opening should be located and marked during the day so it can be easily found again at night. Indirect light may be used when locating the nest at night, but no direct light should be shone into the nest opening. Light shining into the nest will arouse the resting yellowjackets and cause them to attack. For nests that are located in walls, attics, and crawlspaces with easily located entrance holes, insecticide dusts are available. The yellowjackets walk through the dust when they enter and transport the poison on their legs so it spreads through the colony. Professional extermination should also be considered in difficult and more complicated situations (Potter 1994; Bambara and Waldvogel 1999).

Yellowjackets, in particular, can be late-summer and early-fall pests around outdoor eating areas and trash cans, where workers will seek sweets and other food items to support the maturing colony. While not particularly aggressive away from the nest during spring and early summer, they become more aggressive later in the summer and into the fall. During this time of year, people eating outside should keep drinks and food items covered until they are ready to be consumed. Particular care needs to be taken because yellowjackets have a tendency to enter soft drink cans and other containers. Trash cans should be located away from eating areas and equipped with tight-fitting lids.

\section{Removal Methods}

Nests of paper wasps and bald-faced hornets can be knocked down using a broom or similar device once has been determined that they are no longer active. Abandoned underground yellowjacket nests can be left in place. Those in more accessible locations can be removed once deemed to be inactive. 


\section{Disease Concerns}

No major disease concerns are associated with wasps, hornets, or yellowjackets. The main concern is the painful stings that they inflict. These stings can be life-threatening to those allergic to the venom. However, in general, the annoyance is the initial pain of the sting, which can be extremely painful. Swarming hornets and yellowjackets can administer a number of bites at one time, which compounds the pain. If allergic or stung multiple times at once, the employee should immediately seek medical attention at ORNL Medical.

\subsubsection{Mud Daubers}
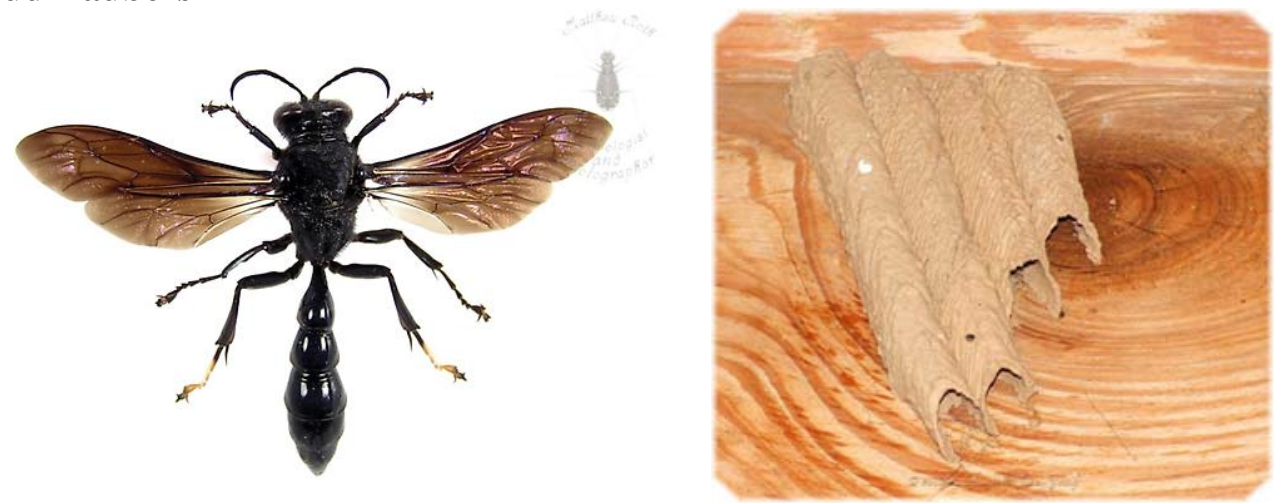

\section{Nuisance Concerns}

Mud daubers are slender wasps that build finger-like nests of mud attached to flat surfaces under roofs and eaves and in outbuildings and attics. They can become a nuisance when nesting in and around buildings people frequent.

Solitary wasps such as mud daubers are different from the social wasps (i.e., paper wasps, hornets and yellowjackets). They have no worker caste, and queens care for their own young. The queens use their sting solely to paralyze prey and not to defend a nest. Therefore, these wasps are relatively nonaggressive and rarely sting unless harassed.

\section{Remedies}

It is usually not necessary to control mud daubers, unless their nests are obstructing everyday activities and/or building maintenance procedures. If so, standard spray insecticides can be used. Because these wasps are nonaggressive and solitary in nature, flyswatters can also be used in many cases.

\section{Removal Methods}

Mud dauber nests can be easily removed with a putty knife. Insecticide sprays might need to be used prior to removal if the nests are still active. Nests should be immediately disposed of to prevent the emergence of developing young (Vail, Williams, and Yanes 1998).

\section{Disease Concerns}

No major disease concerns are associated with mud daubers. The main concern is the sting that they could inflict if disturbed. 


\section{REFERENCES}

Alsop, F. J. III. 2001. Birds of North America, Eastern Region. DK Publishing, Inc., New York.

Bambara, S. B., and M. Waldvogel. 1999. Controlling Bald-faced Hornets and Yellowjackets in and around Structures. North Carolina Cooperative Extension, Department of Entomology, North Carolina State University. Available at http://www.ces.ncsu.edu/depts/ent/notes/Urban/hornyj.htm.

Chapman, J. A., and G. A. Feldhamer. 1982. Wild Mammals of North America. The Johns Hopkins University Press, Baltimore.

Conant, R., and J. T. Collins. 1998. A Field Guide to Reptiles and Amphibians, East/Central North America. Houghton Mifflin Company, New York.

Harper, C. A., J. L. Byford, and C. Dixon. 2003. Managing Nuisance Animals and Associated Damage around the Home. Agricultural Extension Service, University of Tennessee. Available at http://www.utextension.utk.edu/publications/pbfiles/pb1624.pdf.

Harrison, H. H. 1975. A Field Guide to Bird Nests. Houghton Mifflin Company, Boston.

National Geographic Society. 2002. Field Guide to the Birds of North America. National Geographic, Washington, D. C.

Nicholson, C. P. 1997. Atlas of the Breeding Birds of Tennessee. The University of Tennessee Press, Knoxville, Tennessee.

Potter, M. 1994. Controlling Wasps, Hornets and Yellowjackets. University of Kentucky College of Agriculture. Available at http://www.uky.edu/Ag/Entomology/entfacts/struct/ef620.htm.

United States Department of Agriculture. 1994. Prevention and Control of Wildlife Damage. Eds. S. E. Hygnstrom, R. M. Timm, G. E. Larson, University of Nebraska-Lincoln. Available at http://icwdm.org/handbook/index.asp.

Vail, K. M., H. E. Williams, and J. Yanes, Jr. 1998. Mud Daubers and Cicada Killers. SP341-T. Agricultural Extension Service, University of Tennessee. Available at http://www.utextension. utk.edu/publications/spfiles/sp341-T.pdf. 



\section{INTERNAL DISTRIBUTION}

1. W. M. Belvin (DOE at ORNL)

2. G. D. Buckley

3. H. L. Debban

$4 . \quad$ J. W. Evans

5-29. N. R. Giffen

30. G. K. Jacobs

31. R. C. Mann

32. J. O. Moore (DOE at ORNL)

33-37. P. D. Parr

38. M. J. Peterson
39. L. L. Radcliffe (DOE at ORNL)

40. T. J. Rader

41. E. L. Ryan

42. J. W. Smith

43. R. R. Smith

44. J. E. Stone

45. J. Wadsworth

46. S. H. Young

47. ORNL Office of Technical

Information and Classification 
